\title{
Rapid emplacement of the Oman ophiolite: Thermal and geochronologic constraints
}

\author{
B. R. Hacker, J. L. Mosenfelder, and E. Gnos \\ Department of Geological and Environmental Sciences, Stanford University, Stanford, California
}

\begin{abstract}
In understanding of ophiolite emplacement requires knowledge of the elapsed time between igneous crystallization and intraoceanic thrusting, and the rate and duration of that thrusting. Hornblende ${ }^{40} \mathrm{Ar} /{ }^{39} \mathrm{Ar}$ ages demonstrate that the igneous oceanic crust in Oman crystallized and cooled to $\sim 825 \mathrm{~K}$ in 1-2 m.y. Hornblende ages from metamorphic rocks and from cross-cutting dikes require that the basal metamorphic thrust fault beneath the ophiolite also cooled below $\sim 825 \mathrm{~K}$ in 1-2 m.y. Motion along the sole thrust accounted for $200 \mathrm{~km}$ of displacement at a rate of $100-200 \mathrm{~mm} / \mathrm{yr}$. On the basis of age relationships and thermal considerations, we favor a twostage model for the initial stages of Samail ophiolite emplacement: intraoceanic thrusting over $<2$-m.y.-old lithosphere at $150 \mathrm{~km} / \mathrm{m}$.y. parallel to a spreading ridge for 1-2 m.y., followed by equally rapid and brief thrusting over cold and old lithosphere. Preservation of the Samail ophiolite is a direct result of its young age and positive buoyancy at the time of ocean closure, and we propose that all ophiolites that originated near spreading centers and were emplaced onto continents were young at the time of intraoceanic thrusting.
\end{abstract}

\section{Introduction}

The emplacement of oceanic lithosphere onto continents remains one of the great mysteries of plate tectonics - how does ophiolitic material with a density of $3.0-3.3 \mathrm{~g} / \mathrm{cm}^{3}$ rise from its natural depths of $\geq 2.5 \mathrm{~km}$ beneath the ocean surface to elevations more than $1 \mathrm{~km}$ above sea level on continents with densities of $2.7-2.8 \mathrm{~g} / \mathrm{cm}^{3}$ ? The question is most profound for Tethyan-type ophiolites (ophiolites emplaced onto passive continental margins) [Moores, 1982] such as the Samail ophiolite of Oman and the United Arab Emirates. The Samail ophiolite is one of the largest thrust sheets on Earth, with a length of $>400 \mathrm{~km}$ and a width of $150 \mathrm{~km}$ (Figure 1). Understanding its emplacement history influences how we view the process of plate tectonics as a whole.

The two basic tectonic models for the origin and emplacement of the Oman ophiolite are an "arc" model and a "ridge" model. The ridge model [e.g., Boudier et al., 1985] proposes that the Oman ophiolite represents one limb of an oceanic spreading center that was forced over the

Copyright 1996 by the American Geophysical Union.

Paper number 96TC01973.

0278-7407/96/96TC-01973\$12.00 opposite limb and then onto the Arabian continent. The arc model [e.g., Lippard et al., 1986] suggests that the Oman ophiolite originated as an intraoceanic arc or back-arc basin that rode over subducting oceanic lithosphere and then onto the Arabian continent.

One of the most powerful constraints that can be placed on models of ophiolite emplacement is that of time. By determining the age of the ophiolite at the beginning of emplacement and the duration of intraoceanic thrusting, we can constrain the rate of thrusting, the amount of thrusting, the initial position of the ophiolite, and the buoyancy of the ophiolite with respect to the asthenosphere. Estimates of the age of ophiolites at the time of emplacement range from less than 5 m.y. for the Samail ophiolite [Lanphere, 1981; Searle and Malpas, 1980] to 20 m.y. for the Brooks Range, Alaska, ophiolites [Wirth et al., 1993]. In this paper we use ${ }^{40} \mathrm{Ar} /{ }^{39} \mathrm{Ar}$ geochronology to demonstrate that initial stages of emplacement of the Samail ophiolite occurred 1-2 m.y. after igneous crystallization.

\section{The Samail Ophiolite}

The Samail ophiolite of the Sultanate of Oman and the United Arab Emirates is the best-exposed, largest $(>10,000$ $\mathrm{km}^{2}$ ), least-deformed, and perhaps most-studied ophiolite in the world. Reconstructions of spreading center geometry based on the orientations of sheeted dikes and structures within gabbro and ultramafic rocks [e.g., Boudier and Nicolas, 1988] indicate that the width of the ophiolite normal to the paleo-ridge axis is $\sim 200 \mathrm{~km}$ (Figure 1 ). Though now distended by normal faulting, the Samail ophiolite is inferred to have been $15-20 \mathrm{~km}$ thick before its emplacement onto the Arabian craton in Late Cretaceous time (Figure 2). The ophiolite consists of pelagic sedimentary rocks $(\leq 0.1 \mathrm{~km})$, volcanic rocks $(0.5-2.0 \mathrm{~km})$, sheeted dikes (1-1.5 km), gabbro and igneous peridotite $(0.5-6.5 \mathrm{~km})$, peridotite tectonite $(8-12 \mathrm{~km})$, and a basal metamorphic sole $(\leq 0.5 \mathrm{~km})$ [Boudier and Coleman, 1981; Christensen and Smewing, 1981; Lippard et al., 1986; Manghnani and Coleman, 1981; Pallister, 1990].

The petrotectonic setting of the Samail ophiolite is somewhat uncertain. The volcanic rocks have been divided into lower, middle, and upper lavas. Although there is agreement that the uppermost, volumetrically least significant, "V3" lavas erupted from intraplate volcanoes, the petrogenesis of the lower ("V1") and middle ("V2") lavas is under debate. These rocks have been interpreted both as transitional between mid-ocean ridge and intraoceanic arc lavas [Lippard et al., 1986; Pearce et al., 1981 ] and as the products of normal mid-ocean ridge 


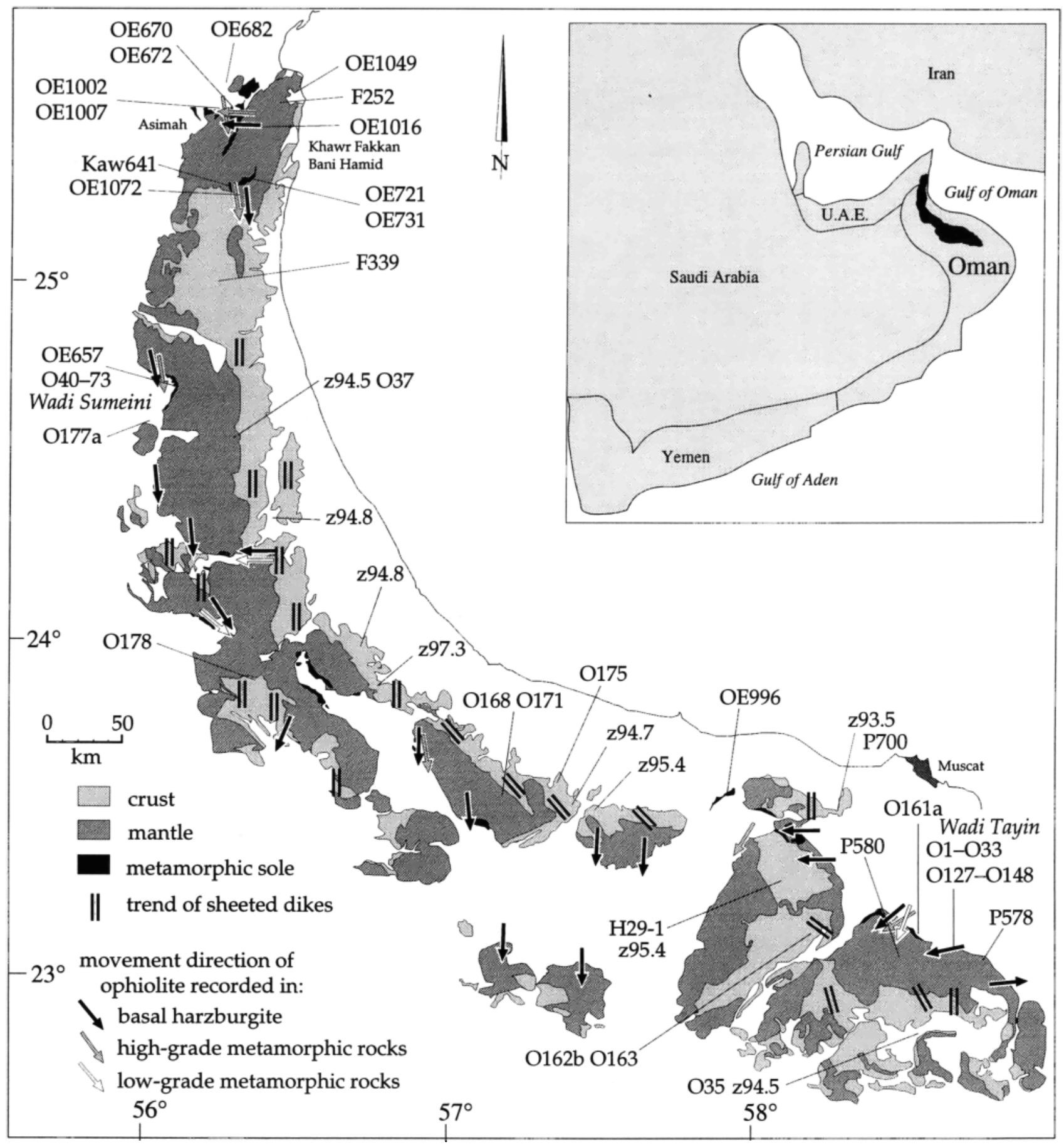

Figure 1. Geologic map of Samail ophiolite, showing locations of Wadi Sumeini and Wadi Tayin. Locations of ${ }^{40} \mathrm{Ar} /{ }^{39} \mathrm{Ar}$ samples from this study are indicated by sample number. Ages (in $\mathrm{Ma}$ ) of U/Pb zircon samples [Tilton et al., 1981] are preceded with a "z". Orientations of sheeted dikes after Nicolas et al. [1988].

spreading and subsequent melt extraction during intraoceanic thrusting [Ernewein et al., 1988; Pflumio, 1991]. Plutonic rocks comprise an early gabbroic series $(60-80 \mathrm{vol} \%$ of the crust) and a late wehrlitic series $(20$ 40\%) [Browning and Smewing, 1981; Juteau et al., 1988; Lippard et al., 1986]. The early series is a gabbro-dioriteplagiogranite suite that was the source of the sheeted dike complex and the lower extrusive unit [Lippard et al., 1986; Nicolas and Boudier, 1991]. The wehrlitic series is dominantly wehrlite, with subordinate dunite, gabbro, plagiogranite, and granite, which intruded all younger crustal rocks before complete crystallization of the gabbroic sequence. It is genetically related to the middle extrusive sequence, V2, and is inferred to have been emplaced during 


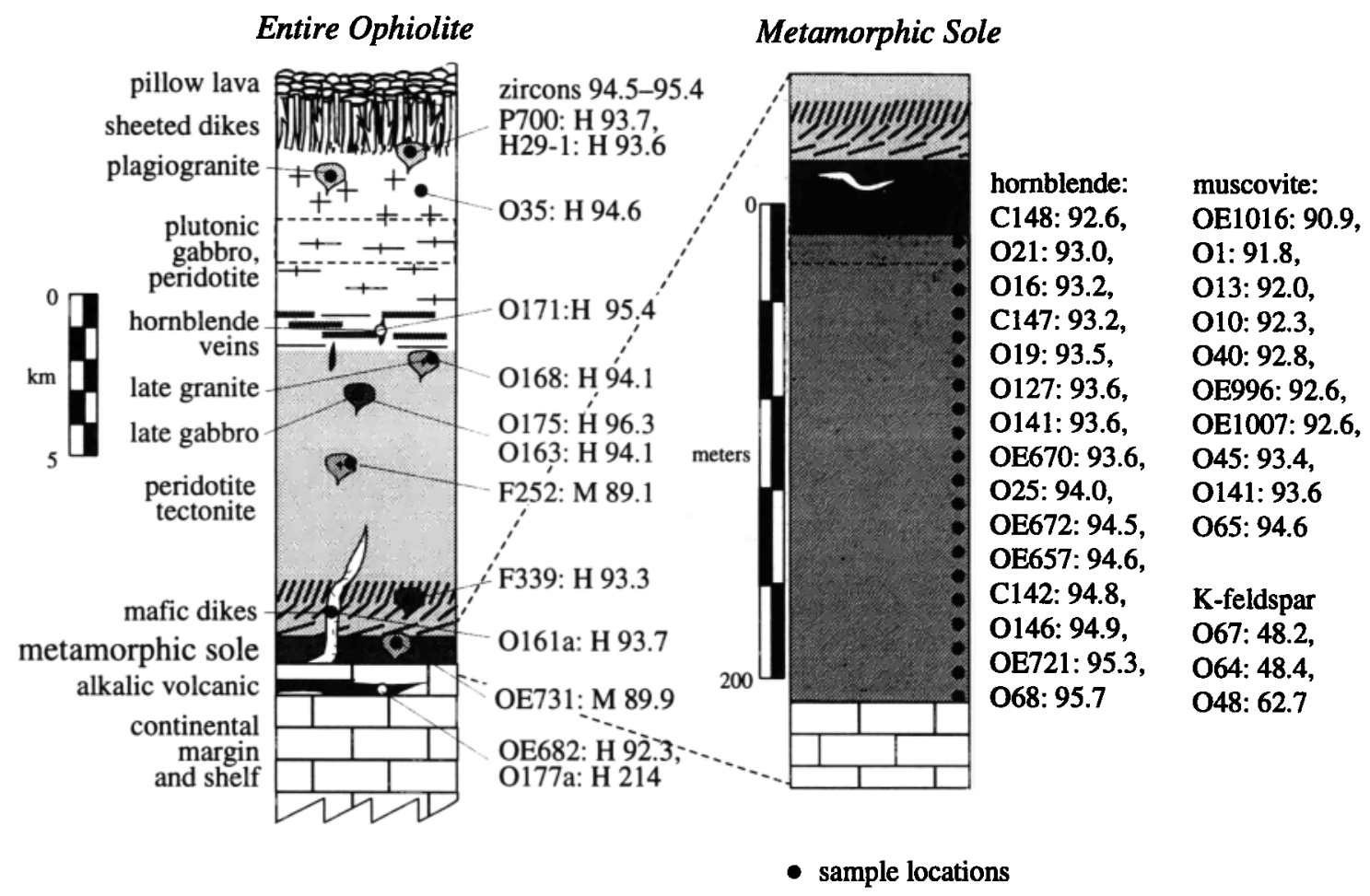

Figure 2. Interpretive pseudostratigraphic section through the Samail ophiolite based on Boudier and Coleman [1981], Christensen and Smewing [1981], Lippard et al. [1986], Manghnani and Coleman [1981], Pallister and Hopson [1981], showing sample localities, $\mathrm{Pb} / \mathrm{U}$ zircon ages [Tilton et al., 1981], ${ }^{40} \mathrm{Ar} /{ }^{39} \mathrm{Ar}$ hornblende ages $(\mathrm{H})$, muscovite ages $(\mathrm{M})$, biotite ages $(\mathrm{B})$, and $\mathrm{K}$-feldspar ages (K). Samples from metamorphic sole are listed by increasing age.

the initial intraoceanic thrusting stage of ophiolite emplacement [Juteau et al., 1988]. The main field distinctions between the gabbroic and wehrlitic series are that the gabbroic series rocks occupy a pseudostratigraphic position above layered mafic-ultramafic rocks and below sheeted dikes and that they share gradational contacts with these two rock types. In contrast, rocks of the wehrlitic series intruded all levels of the crustal sequence and have discordant intrusive contacts, particularly in the upper crust.

The granites may have formed by one or more of four processes: (1) melting of the metamorphic sole [Boudier et al., 1988; Searle and Malpas, 1982]; (2) melting of the underlying continental crust [Lippard et al., 1986]; (3) latestage differentiation of the wehrlitic series [Peters and Kamber, 1994], or (4) remelting of the Samail intrusive sequence driven by devolatilization of the metamorphic sole [Peters and Kamber, 1994].

The Samail ophiolite was thrust over adjacent oceanic lithosphere and then onto the Arabian craton along a several-hundred-meter thick shear zone or "metamorphic sole" composed of partially melted amphibolite-facies mafic rock passing rapidly downward into lower grade sedimentary and mafic rocks [Boudier et al., 1988; Ghent and Stout, 1981; Searle and Malpas, 1980]. Outcrops of the sole on the $\mathrm{E}$ and $\mathrm{W}$ sides of the ophiolite imply that the sole extends beneath the entire ophiolite. Immediately beneath the sole are relatively unmetamorphosed sedimentary and volcanic rocks interpreted as pelagic, slope, rise, and shelf deposits from a Late Permian to Late Cretaceous passive margin and ocean basin that lay NE of the Arabian craton [Glennie et al., 1974; Lippard et al., 1986; Robertson et al., 1990]. The amphibolite-facies rocks may represent oceanic gabbro and basalt overridden during the early, intraoceanic thrusting stage of emplacement. The lower grade rocks are inferred to be basalt, clastic sediment, and chert overridden at a later stage before final emplacement onto the craton [Searle and Malpas, 1980]. Paleogeographic reconstructions suggest that the ophiolite formed 400-500 km offshore [Bechennec et al., 1988, 1990]. The ophiolite thrust sheet moved $\sim 150 \mathrm{~km}$ over underlying rocks [Bechennec et al., 1990]; the remaining 250-350 km was accommodated at deeper structural levels within telescoped pelagic, slope, rise, and shelf deposits of the Middle Triassic to Late Cretaceous passive margin and ocean basin [Glennie et al., 1974; Lippard et al., 1986; Robertson et al., 1990; Searle and Malpas, 1980].

Beneath the metamorphic sole are oceanic sedimentary and volcanic rocks called the Haybi and Hawasina Complexes. The Haybi Complex includes the Haybi volcanics, which are dominantly tholeiitic in composition except near the base where they are alkalic. Throughout the Haybi Complex and in the upper part of the Hawasina Complex are rare alkalic ultramafic and mafic sills [Lippard, 1984; Searle, 1984]. Crystallization ages on these 
igneous rocks constrain their earliest burial beneath the Samail thrust sheet. K/Ar hornblende ages range from 92 to 233 Ma [Lippard and Rex, 1982].

\section{Existing Radiometric Data}

Crystallization ages of the Samail crustal section are well determined by 13 nearly concordant $\mathrm{U} / \mathrm{Pb}$ zircon ages [Tilton et al., 1981] from plagiogranites interpreted as latestage differentiates of the crustal section [Juteau et al., 1988; Lippard et al., 1986; Reuber, 1988; Tilton et al., 1981]. At least one of the plagiogranites dated by Tilton et al. [1981] was inferred to be part of the later wehrlitic suite. Zircons from this body are the same age as the plagiogranites inferred to be part of the main gabbroic series, supporting the suggestion by Juteau et al. [1988] that the wehrlitic series intruded prior to complete solidification of the gabbroic series. The zircon ages range from $97.3 \pm 0.25$ to $93.5 \pm 0.25 \mathrm{Ma}(1 \sigma)$ (Figure 1 ). Ten ages are restricted to a rather narrow interval of 95.4 to 94.5 Ma (Figure 3), with a mean age of $94.8 \pm 0.1 \mathrm{Ma}$. Radiolaria in the lower V1 volcanics are Cenomanian and foraminifera in the middle V2 volcanics are Cenomanian to Turonian [Beurrier et al., 1987; Schaaf and Thomas, 1986; Tippit et al., 1981]. The Cretaceous timescale of Gradstein et al. [1994] shows that the Cenomanian and Turonian span 98.9-93.5 $\mathrm{Ma}$ and 93.5-89.0 Ma, respectively. Thus, the $\mathrm{U} / \mathrm{Pb}$ plagiogranite ages agree, within uncertainty, with the fossil ages of the lower and middle volcanic rocks of the ophiolite.

The best way to determine the age of an ophiolite at the beginning of the emplacement process is to determine the cooling ages of minerals from the metamorphic sole. Many $\mathrm{K} / \mathrm{Ar}$ and ${ }^{40} \mathrm{Ar} /{ }^{39} \mathrm{Ar}$ ages from the metamorphic sole were published prior to this study (Figure 3 ). Previously published K/Ar ages from hornblendes ranged from 101 to $89 \mathrm{Ma}$, and clustered near $98 \mathrm{Ma}$ [Allemann and Peters, 1972; Gnos and Peters, 1993; Lanphere, 1981; Lippard et al., 1986; Montigny et al., 1988; Searle et al., 1980]. The wide range in hornblende ages was used to conclude that formation of the metamorphic rocks was a protracted event [Lippard et al., 1986], beginning perhaps as early as 120 Ma [Gnos and Peters, 1993]. The difficulty with this conclusion is that thermomechanical models using an ophiolite that was $\geq 5 \mathrm{~m}$.y. old at the time of emplacement [Hacker, 1990] did not reproduce either the peak metamorphic temperatures inferred for the sole nor the wide range in $\mathrm{K} / \mathrm{Ar}$ ages. Either the inferences drawn from the modeling were incorrect, or the Oman ophiolite was less than 5 m.y. old at the time of emplacement. Further thermomechanical models varying the age of the ophiolite [Hacker, 1991] were able to replicate the peak metamorphic temperatures inferred for the sole and the wide range in $\mathrm{K} / \mathrm{Ar}$ ages only if the ophiolite was $<2 \mathrm{~m}$.y.

Figure 3. Compendium of ages. Italicized ages are interpreted to reflect excess ${ }^{40} \mathrm{Ar}$. Superscripts indicate source: Gnos and Peter [1993] , Tilton et al. [1981] $]^{2}$, Searle et al. $[1980]^{3}$, Allemann and Peters $[1972]^{4}$, Lippard $[1983]^{5}$, Lanphere $[1981]^{6}$, Montigny et al. [1988] ${ }^{7}$. Unlabeled ages are from this study.

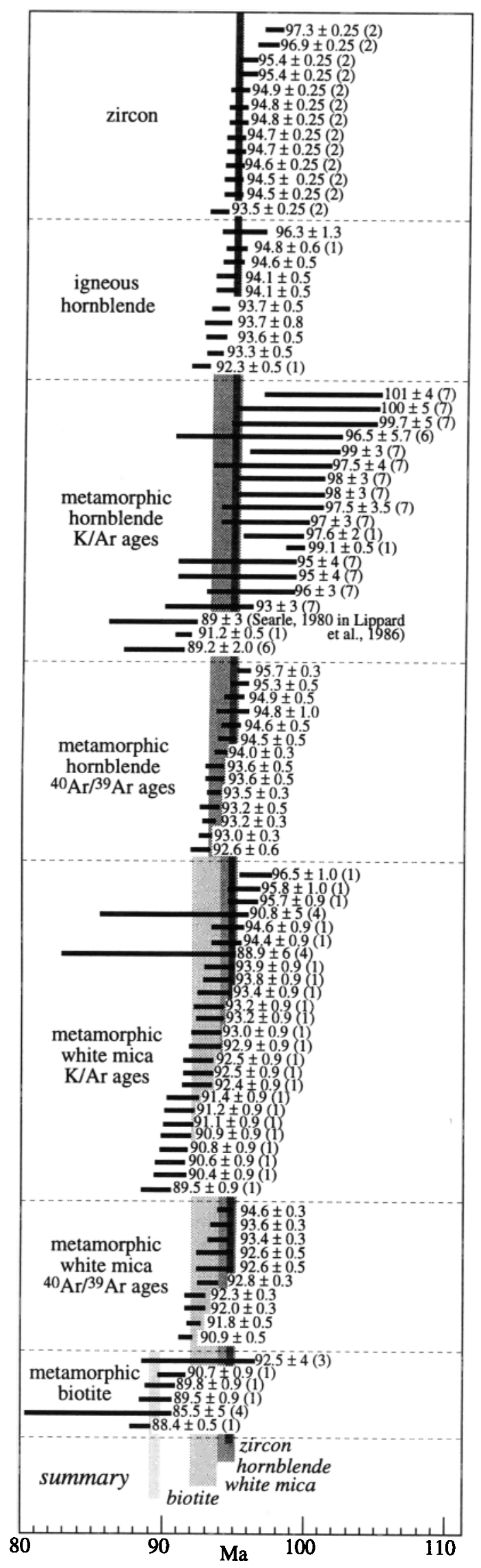


old. This conclusion was earlier reached by Boudier et al. [1988] based on nappe geometry and thickness and olivine fabrics in peridotite.

The large uncertainties of published K/Ar hornblende ages (typically with $2 \sigma$ greater than 6 m.y.) also precluded precise measurement of the time interval between igneous crystallization of the ophiolite and subsequent intraoceanic thrusting. Some hornblende $\mathrm{K} / \mathrm{Ar}$ ages actually predate plagiogranite crystallization of the ophiolite, posing a particular dilemma and spawning suggestions that the metamorphic rocks formed before the ophiolite [Gnos and Peters, 1993; Montigny et al., 1988]. In the following sections we demonstrate that the Samail ophiolite was $\sim 1-2$ m.y. old at the time intraoceanic thrusting began and that it cooled rapidly by thrusting over cold material.

\section{Analytical Techniques}

Mica and feldspar separates were prepared by crushing, sieving, washing in $\mathrm{H}_{2} \mathrm{O}$, and handpicking. Preparation of hornblende separates involved heavy liquids, a hand-held magnet, and a modified Frantz isodynamic separator. All separates were handpicked repeatedly under a binocular microscope until only desired monomineralic grains remained. Following rinsing in acetone and isopropyl alcohol, the separates were wrapped in $\mathrm{Cu}$ or $\mathrm{Al}$ foil, baked at $125^{\circ} \mathrm{C}$ for 1 hour in air, sealed in quartz vials, and irradiated at the TRIGA reactor at Oregon State University for 16 or $24 \mathrm{MWhr}$. Ratios of reactor-produced $\mathrm{Ca}$ and $\mathrm{K}$ were established by analyzing $\mathrm{K}$ and $\mathrm{Ca}$ salts included in previous and subsequent irradiations. Sanidine from the Taylor Creek rhyolite, with an assumed age of $27.92 \pm 0.17$ Ma [Duffield and Dalrymple, 1990], was used as a neutron flux monitor. The monitor packets were interspersed between every 5 or 6 unknown packets; $1-2 \mathrm{mg}$ of each monitor were analyzed with a $6-\mathrm{W}$ model 2016 SpectraPhysics laser in 6 groups of 3-5 grains to determine irradiation parameter, $J$. We used an uncertainty of $0.5 \%$ (at $1 \sigma)$ for $J$ for all samples. Sanidine monitors were gettered for $2 \mathrm{~min}$. Laser blanks were typically $2 \times 10^{-16}$ moles for $\mathrm{m} / \mathrm{e} 40$, and signal sizes for monitors were $-2-20 \times 10^{-14}$ moles.

Resistance furnace analyses were conducted in a doublevacuum Staudacher-type resistance furnace. Except for feldspar crystals, each heating cycle comprised $2 \mathrm{~min}$ of heating from $\sim 250^{\circ} \mathrm{C}$ to the set temperature, $10 \mathrm{~min}$ of constant temperature, and 5-10 minof gettering with SAES ST172 Zr-V-Fe getters operated at $4 \mathrm{~A}$. The collected gas was analyzed for 6-12 min in an MAP-216 spectrometer with a Baur-Signer source operating in static mode with a room temperature SAES ST707 Zr-V-Fe getter. Accelerating voltage was $3 \mathrm{kV}$ and the filament current 3.9 A. Output from a Johnson MM-1 electron multiplier operated at $1.6 \mathrm{kV}$ was measured using a Keithley 617 electrometer in current mode. Peak heights at the time of gas introduction into the mass spectrometer were determined by extrapolating the evolved signal size using a linear regression. The mass discrimination, determined by analyzing the ${ }^{40} \mathrm{Ar} /{ }^{36} \mathrm{Ar}$ ratio of air, was $0.9972 \pm 0.002$ per a.m.u. during the course of these experiments. Resistance furnace $\mathrm{m} / \mathrm{e} 40$ blanks varied from $\sim 1 \times 10^{-16}$ moles at $800^{\circ} \mathrm{C}$ to $\sim 1 \times 10^{-15}$ at $1400^{\circ} \mathrm{C}$.

Internally and externally concordant refer to statistically indistinguishable intrasample and intersample ages, respectively. Uncertainties for ages quoted in this paper are $1 \sigma$ standard deviation, unless otherwise noted. Uncertainties for groups of ages that are averaged are standard errors. To evaluate intersample uncertainty, two sets of samples were split in half, irradiated within the same quartz vial, and analyzed separately. One K-white mica separate from sample $\mathrm{O} 13$ containing micron-scale graphite inclusions gave a weighted mean plateau age of $92.1 \pm 0.3$ Ma. A second, much smaller separate without inclusions yielded an age of $91.8 \pm 0.3 \mathrm{Ma}$. K-white mica sample $\mathrm{O} 45$ yielded a weighted mean plateau age of $93.4 \pm 0.3 \mathrm{Ma}$ from one sample heated in the resistance furnace, and a weighted mean age of $93.5 \pm 0.3 \mathrm{Ma}$ from six concordant laser shots. Yet another sample, O35, was split and each half was irradiated separately 1 year apart. The first split yielded isochron and plateau ages of $94.65 \pm 0.5$ and $94.58 \pm 0.5$ $\mathrm{Ma}$, while the second produced isochron and plateau ages of $94.20 \pm 0.3$ and $94.25 \pm 0.3 \mathrm{Ma}$. Thus, the difference between replicate analyses of the same samples and between separate irradiations is less than the analytical uncertainty. Cited mineral compositions were determined by electron microprobe.

\section{New ${ }^{40} \mathbf{A r}{ }^{\beta 9}$ Ar Data}

The primary objective of our study was to constrain the crystallization or cooling ages of as many rocks of the ophiolite suite as possible. To this end, we dated (Tables 1 and $A 1^{1}$; Figure 2): (1) plagiogranite and gabbro from the gabbroic and wehrlitic series; (2) late-stage granites; (3) hornblende veins in the layered cumulate peridotite and gabbro; (4) the metamorphic sole from two localities sampled in detail and several localities sampled in reconaissance; (5) diabase dikes intruding the metamorphic sole and the harzburgite tectonite; and (6) the Haybi volcanics.

The large number of radiometric dates in this study requires that the data be discussed in groups rather than individually. More than half the samples yielded spectra that are straightforward to interpret (Figure 4). A significant fraction of the temperature steps in each of these spectra are internally concordant-that is, the steps form a plateau. Isotope correlation diagrams for all these samples reveal simple two-component mixing between $\mathrm{Ar}$ derived by in situ ${ }^{40} \mathrm{~K}$ decay and trapped atmospheric Ar. The lowest temperature gas fractions released from many of these samples typically have ${ }^{39} \mathrm{Ar} /{ }^{38} \mathrm{Ar}$ (proportional to $\mathrm{K} / \mathrm{Cl}$ ) and ${ }^{39} \mathrm{Ar} /{ }^{37} \mathrm{Ar}$ (proportional to $\mathrm{K} / \mathrm{Ca}$ ) ratios that are

\footnotetext{
${ }^{1}$ Supporting data in Table A1 are available on diskette or via anonymous FTP from kosmos.agu.org, directory APEND (Username $=$ anonymous, Password $=$ guest). Diskette may be ordered from American Geophysical Union, 2000 Florida Avenue, N.W., Washington, DC 20009 or by phone at $800-966-2481 ; \$ 15.00$. Payment must accompany order.
} 
Table 1. Summary of ${ }^{40} \mathrm{Ar} /{ }^{39} \mathrm{Ar}$ Data

\begin{tabular}{|c|c|c|c|c|c|c|c|c|c|}
\hline No & $\mathbf{x l}$ & TFA & WMPA & IA & MSWD & ${ }^{40} \mathrm{Ar} /{ }^{36} \mathrm{Ar}$ & Steps & ${ }^{39} \mathrm{Ar}$ & prev. age \\
\hline $\mathrm{C} 147$ & hb & $92.3 \pm 1.8$ & $93.2 \pm 0.5$ & $91.7 \pm 1.2$ & 0.50 & $314 \pm 10$ & $5-10 / 10$ & 86 & \\
\hline C148* & hb & $95.1 \pm 0.2$ & - & $92.6 \pm 0.6$ & 0.56 & $329.2 \pm 7.0$ & $6-11 / 11$ & 79 & \\
\hline F 252 & mu & $89.2 \pm 0.4$ & $89.1 \pm 0.4$ & $89.2 \pm 0.4$ & 0.54 & $269 \pm 10 \dagger$ & $14-18 / 19$ & 57 & $89.6 \pm 8$ \\
\hline F339 & $\mathrm{hb}$ & $91.7 \pm 0.5$ & $93.3 \pm 0.5$ & $91.0 \pm 3.4$ & 0.67 & $304 \pm 10$ & $5-20 / 20$ & 80 & $92.3 \pm 0.5$ \\
\hline H29-1 & $\mathrm{hb}$ & $92.8 \pm 1.1$ & $93.6 \pm 0.5$ & $93.7 \pm 0.5$ & 0.69 & $292.9 \pm 0.5$ & $1-18 / 18$ & 100 & $95.4 \pm 0.5$ (zircon) \\
\hline Kaw641 & bi & $91.2 \pm 0.5$ & & & & & & & $89.5 \pm 0.9$ \\
\hline 01 & $\mathrm{mu}$ & $89.8 \pm 0.5$ & $91.8 \pm 0.5$ & $91.9 \pm 0.5$ & 1.07 & $286 \pm 12$ & $4-14 / 14$ & 59 & \\
\hline O5 & $\mathrm{hb}$ & $95.6 \pm 0.5$ & & & & & & & \\
\hline 010 & $\mathrm{mu}$ & $93.5 \pm 0.3$ & $92.3 \pm 0.3$ & $92.6 \pm 0.4$ & 0.10 & $296.2 \pm 22$ & $8-10 / 10$ & 20 & \\
\hline 011 & hb & $92.2 \pm 0.3$ & - & - & - & - & $7-8 / 11$ & 49 & \\
\hline O13+ & $\mathrm{mu}$ & $92.4 \pm 0.3$ & $92.1 \pm 0.3$ & $92.1 \pm 0.3$ & 0.67 & $301 \pm 16$ & $6-10 / 10$ & 63 & \\
\hline O13- & $\mathrm{mu}$ & $92.3 \pm 0.4$ & $91.8 \pm 0.3$ & $91.9 \pm 0.3$ & 0.80 & $288 \pm 12$ & $5-10 / 10$ & 69 & \\
\hline O16* & hb & $93.7 \pm 0.3$ & $93.2 \pm 0.3$ & $93.3 \pm 0.4$ & 0.88 & $294.0 \pm 6.5$ & $4-9 / 11$ & 69 & \\
\hline O19* & hb & $90.3 \pm 0.5$ & $93.5 \pm 0.3$ & $93.6 \pm 0.3$ & 0.34 & $298.3 \pm 1.6$ & $8-12 / 12$ & 77 & \\
\hline $\mathrm{O} 21 *$ & hb & $91.6 \pm 0.3$ & $93.0 \pm 0.3$ & $92.8 \pm 0.3$ & 0.57 & $301.4 \pm 2.7$ & $5-15 / 15$ & 86 & \\
\hline $\mathrm{O} 25^{*}$ & hb & $93.1 \pm 0.3$ & $94.0 \pm 0.3$ & $94.2 \pm 0.3$ & 0.68 & $297.4 \pm 2.2$ & $7-11 / 11$ & 52 & \\
\hline O30 & hb & $91.9 \pm 0.3$ & & & & & & & \\
\hline O32* & hb & $94.2 \pm 0.6$ & & & & & & & \\
\hline $\mathrm{O} 33$ & $\mathrm{hb}$ & $93.2 \pm 0.3$ & & & & & & & \\
\hline O35 (H30-1) & $\mathrm{hb}$ & $94.8 \pm 2.1$ & $94.6 \pm 0.5$ & $94.7 \pm 0.5$ & 0.75 & $291 \pm 11$ & $7-16 / 17$ & 86 & $94.5 \pm 0.5$ (zircon) \\
\hline O37 (OU-1) & hb & $88.3 \pm 0.5$ & - & - & - & - & - & - & $94.5 \pm 0.5$ (zircon) \\
\hline 040 & $\mathrm{mu}$ & $93.1 \pm 0.3$ & $92.8 \pm 0.3$ & $92.9 \pm 0.3$ & 2.50 & $280 \pm 12$ & $4-10 / 10$ & 85 & \\
\hline O45las & $\mathrm{mu}$ & $93.5 \pm 0.3$ & $93.5 \pm 0.3$ & $93.5 \pm 0.5$ & 0.70 & $294 \pm 12$ & 6 shots & 100 & \\
\hline O45rf & $\mathrm{mu}$ & $93.5 \pm 0.3$ & $93.4 \pm 0.3$ & $93.4 \pm 0.3$ & 0.61 & $290 \pm 10$ & $5-10 / 10$ & 92 & \\
\hline O48 & Ksp & $63.1 \pm 0.2$ & “62.7 \pm 0.2 " & - & - & - & - & - & \\
\hline O56 & hb & $104.7 \pm 0.4$ & - & - & - & $\sim 1018$ & - & - & \\
\hline O57 & $\mathrm{hb}$ & $91.9 \pm 0.5$ & - & $93.5 \pm 0.6$ & 2.2 & $348 \pm 32$ & $11-17 / 18$ & 72 & \\
\hline O64 & Ksp & $48.1 \pm 0.2$ & $“ 48.4 \pm 0.2 "$ & - & - & - & - & - & \\
\hline O65 & $\mathrm{mu}$ & $94.6 \pm 0.3$ & - & - & - & - & - & - & \\
\hline O67 & ksp & $48.2 \pm 0.2$ & - & - & - & - & - & - & \\
\hline O68 & $\mathrm{hb}$ & $91.7 \pm 0.3$ & $95.7 \pm 0.3$ & $95.4 \pm 0.5$ & 0.60 & $315 \pm 21$ & $8-12 / 12$ & 66 & \\
\hline O73 & $\mathrm{hb}$ & $97.4 \pm 0.3$ & - & - & - & - & - & - & \\
\hline O127 & $\mathrm{hb}$ & $91.5 \pm 0.5$ & $93.6 \pm 0.5$ & $93.7 \pm 0.8$ & 0.60 & $294.7 \pm 6.5$ & $6-23 / 23$ & 54 & \\
\hline O134 & $\mathrm{hb}$ & $71.0 \pm 2.0$ & & & & & & & \\
\hline 0141 & $\mathrm{mu}$ & $92.5 \pm 0.6$ & $93.6 \pm 0.5$ & $93.6 \pm 0.5$ & 0.60 & $293.4 \pm 0.4$ & $3-17 / 17$ & 98 & \\
\hline C142* & $\mathrm{hb}$ & $92.4 \pm 2.1$ & $94.8 \pm 1.0$ & $94.6 \pm 3.1$ & 0.11 & $296.5 \pm 5.4$ & $6-11 / 11$ & 78 & \\
\hline 0146 & $\mathrm{hb}$ & $94.4 \pm 0.5$ & $94.9 \pm 0.5$ & $95.0 \pm 0.5$ & 0.50 & $290.3 \pm 3.5$ & $9-17 / 17$ & 89 & \\
\hline O161a & $\mathrm{hb}$ & $95.5 \pm 0.9$ & $93.7 \pm 0.8$ & $93.8 \pm 2.1$ & 3.1 & $299 \pm 19$ & $1-8 / 10$ & 92 & \\
\hline $0162 b$ & hb & $92.9 \pm 2.8$ & & & & & & & \\
\hline 0163 & hb & $93.3 \pm 0.5$ & $94.1 \pm 0.5$ & $94.0 \pm 0.5$ & 0.90 & $300 \pm 21$ & $10-19 / 19$ & 67 & \\
\hline 0168 & hb & $94.7 \pm 0.8$ & $94.1 \pm 0.5$ & $94.1 \pm 0.5$ & 1.35 & $296.5 \pm 1.3$ & $1-12 / 12$ & 100 & \\
\hline 0171 & hb & $95.6 \pm 0.8$ & $95.4 \pm 0.5$ & $95.8 \pm 1.1$ & 0.10 & $286.4 \pm 6.9$ & $13-17 / 17$ & 63 & \\
\hline 0175 & hb & $100.2 \pm 4.5$ & $97.1 \pm 0.8$ & $96.3 \pm 1.3$ & 0.67 & $302.8 \pm 6.6$ & $7-14 / 15$ & 88 & \\
\hline O177a & hb & $210.6 \pm 1.0$ & $214.1 \pm 1.0$ & $214.2 \pm 1.0$ & 0.30 & $278 \pm 11$ & $14-16 / 17$ & 18 & \\
\hline 0178 & hb & $89.4 \pm 2.3$ & & & & & & & \\
\hline OE657 & hb & $94.6 \pm 0.5$ & $94.6 \pm 0.5$ & $94.5 \pm 0.5$ & 0.63 & $296.3 \pm 4.2$ & $4-15 / 23$ & 77 & \\
\hline OE670 & hb & $100.6 \pm 0.5$ & $98.7 \pm 0.5$ & $93.6 \pm 0.6$ & 1.67 & $337.7 \pm 3.0$ & $10-26 / 26$ & 39 & \\
\hline OE672 & bi & $62.7 \pm 0.4$ & & & & & & & $76.7 \pm 0.8$ \\
\hline OE672 & hb & $95.5 \pm 0.5$ & $94.5 \pm 0.5$ & $94.3 \pm 0.6$ & 0.09 & $302.9 \pm 3.3$ & $8-12 / 22$ & 42 & $101.8 \pm 0.8$ \\
\hline OE682 & hb & $92.2 \pm 0.5$ & $92.3 \pm 0.5$ & $92.4 \pm 0.5$ & 0.51 & $*$ & $9-18 / 28$ & 86 & \\
\hline OE721 & hb & $96.2 \pm 0.5$ & $95.3 \pm 0.5$ & $95.1 \pm 0.6$ & 0.85 & $302.7 \pm 8.2$ & $12-20 / 28$ & 44 & $99.1 \pm 0.5$ \\
\hline OE731 & $\mathrm{mu}$ & $89.7 \pm 0.4$ & $89.9 \pm 0.4$ & $89.8 \pm 0.4$ & 1.0 & $298.6 \pm 3.3$ & $7-41 / 41$ & 95 & $91.1 \pm 0.9$ \\
\hline OE996 & $\mathrm{mu}$ & $92.7 \pm 0.5$ & $92.6 \pm 0.5$ & $92.5 \pm 0.5$ & 0.64 & $296.8 \pm 1.8$ & $4-26 / 28$ & 72 & $92.5 \pm 0.9$ \\
\hline $\mathrm{OE} 1002$ & bio & $77.4 \pm 0.4$ & & & & & & & \\
\hline OE1007 & bio & $69.4 \pm 0.4$ & & & & & & & $38.6 \pm 0.4$ \\
\hline OE1007 & $\mathrm{mu}$ & $92.7 \pm 0.5$ & $92.6 \pm 0.5$ & $92.7 \pm 0.5$ & 1.57 & $290.4 \pm 9.3$ & $4-24 / 27$ & 84 & \\
\hline OE1016 & $\mathrm{mu}$ & $91.0 \pm 0.5$ & $90.9 \pm 0.5$ & $90.9 \pm 0.5$ & 1.1 & $295.3 \pm 1.1$ & $1-27 / 27$ & 100 & $91.2 \pm 0.9$ \\
\hline OE1049 & bio & $128.3 \pm 1.4$ & & & & & & & $71.0 \pm 0.7$ \\
\hline OE1072 & bio & $82.8 \pm 0.5$ & & & & & & & $60.4 \pm 0.6$ \\
\hline P578-2 & $\mathrm{hb}$ & $99.8 \pm 0.6$ & & & & & & & \\
\hline P580-2 & hb & $85.6 \pm 1.0$ & & & & & & & \\
\hline
\end{tabular}


Table 1. (continued)

\begin{tabular}{lccccccccc}
\hline No & xl & TFA & WMPA & IA & MSWD & ${ }^{40} \mathrm{Ar} /{ }^{36} \mathrm{Ar}$ & Steps & ${ }^{39} \mathrm{Ar}$ & prev. age \\
\hline P700 & hb & $93.0 \pm 2.8$ & $\mathbf{9 3 . 7} \pm \mathbf{0 . 5}$ & $93.8 \pm 0.6$ & 1.1 & $289 \pm 11$ & $4-18 / 19$ & 89 & $93.5 \pm 0.5(\mathrm{zircon})$ \\
\hline
\end{tabular}

Plateau ages in quotes designate ages derived from steps that are internally concordant at the $67 \%$ rather than the $95 \%$ confidence level. MSWD is the mean square weighted deviation [Wendt and Carl, 1991], which expresses the goodness of fit of the isochron [Roddick, 1978]; isochron and weighted mean plateau ages are based on temperature steps and fraction of ${ }^{39} \mathrm{Ar}$ listed in the last two columns. Abbreviations are hb, hornblende; bio, biotite; mu, K-white mica; Ksp, K-feldspar. For complete tabulated data see the electronic supplement.

Sample names in parentheses are those of Tilton et al. [1981]

* Reported previously [Hacker, 1994]

† Sample is so radiogenic that ${ }^{40} \mathrm{Ar} /{ }^{36} \mathrm{Ar}$ intercept is poorly defined.
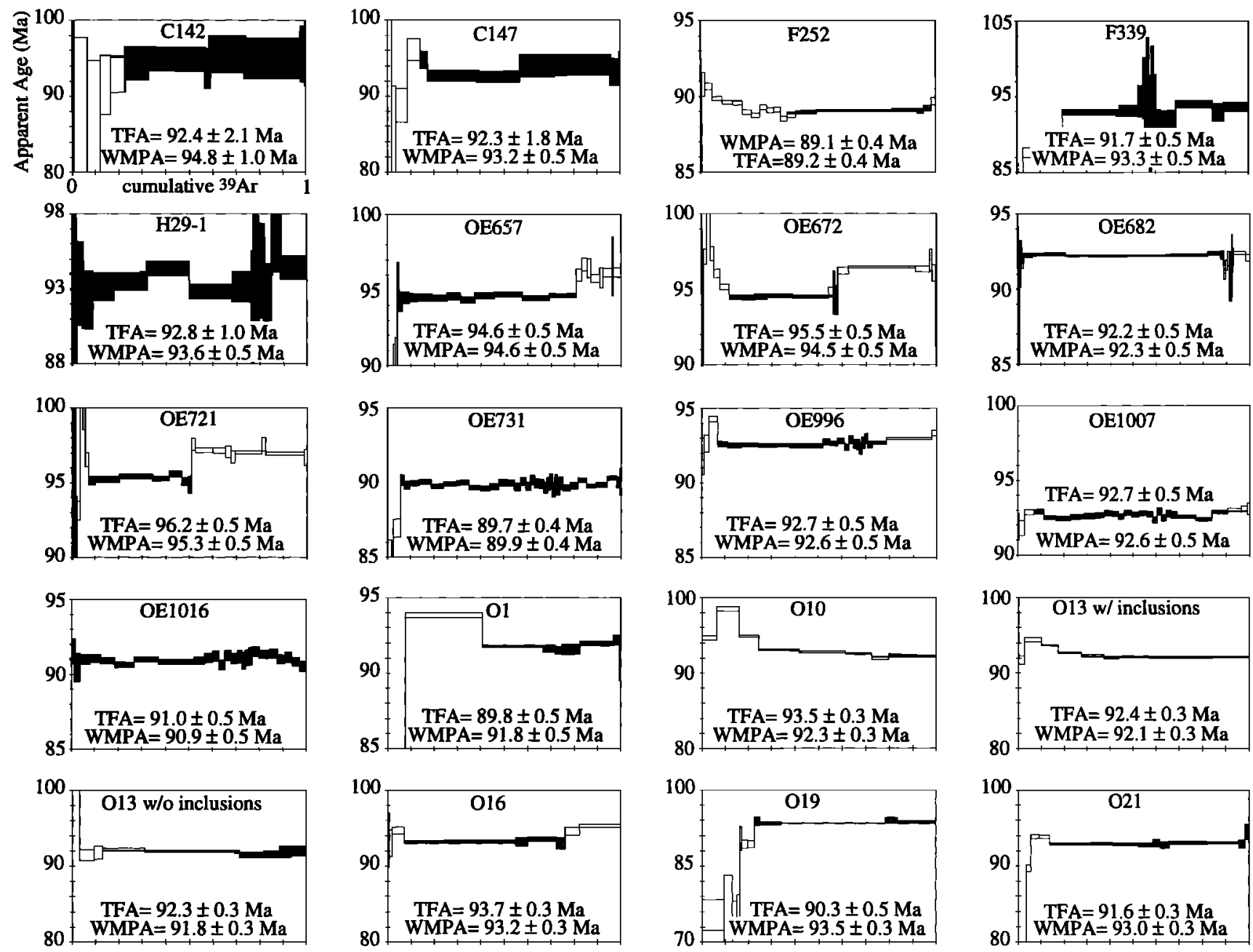

Figure 4. Spectra yielding plateau ages. Shading indicates internally concordant steps used to compute weighted mean plateau age. One-sigma uncertainties shown excluding error in irradiation parameter, $J$. TFA, total fusion age; WMPA, weighted mean plateau age. Solid boxes show concordant steps used to calculate WMPA. 

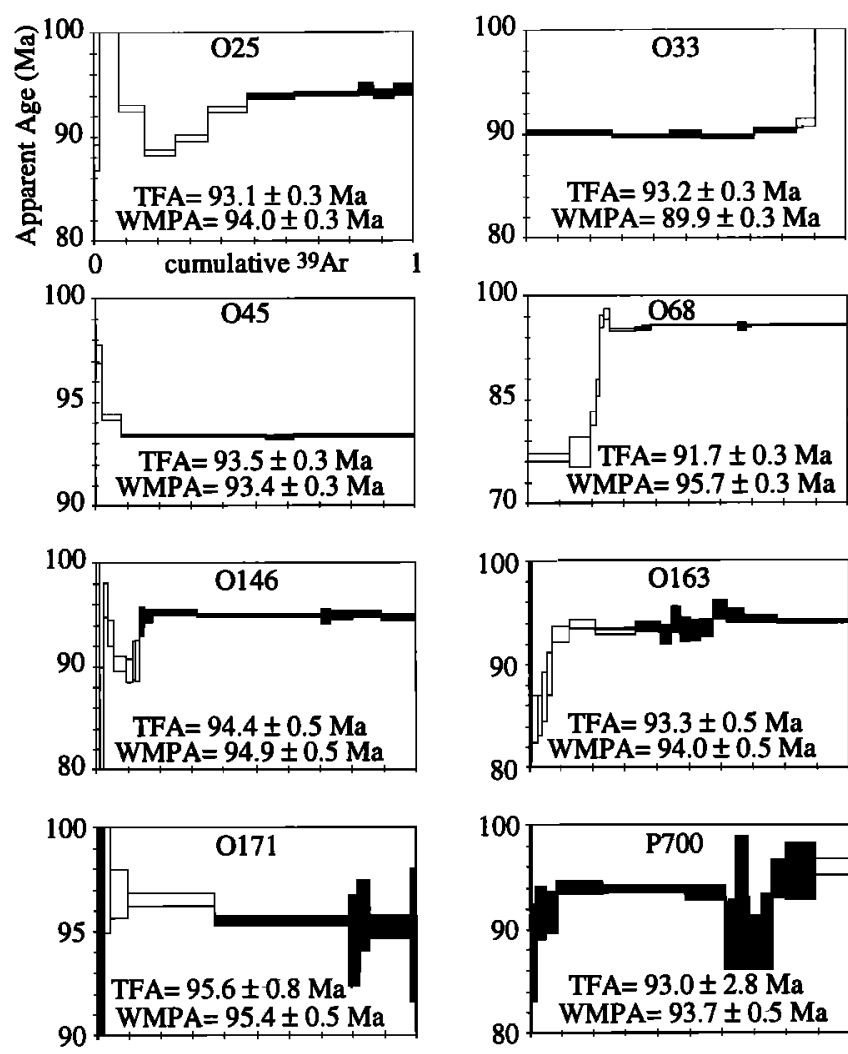
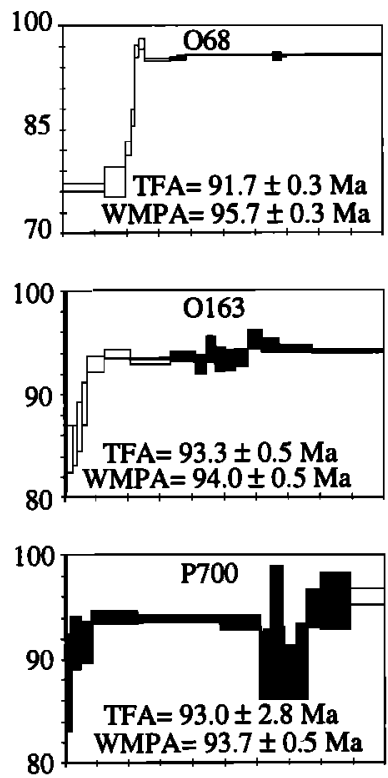
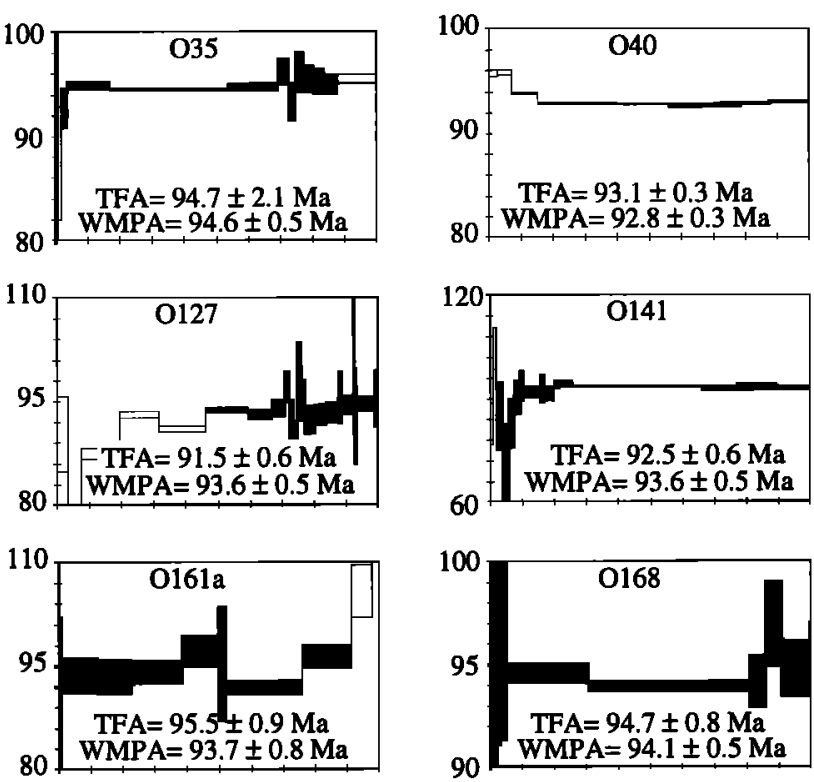

Figure 4. (continued)

different from the bulk of the released gas, suggesting the decomposition of phase(s) or domain(s) of different composition at low temperatures; apparent ages of these fractions are often discordant to the remainder of the spectrum and were not used in calculating sample ages. For all these well-behaved samples with trapped atmospheric $\mathrm{Ar}$, we use the weighted mean plateau age for the sample rather than the isochron age. Both types of age are statistically indistinguishable for these samples, but because the isotope correlations suggest atmospheric contamination, we prefer the spectrum ages, which are calculated assuming that the trapped nonradiogenic Ar is atmosphere.

About one dozen samples clearly contain excess ${ }^{40} \mathrm{Ar}$, as indicated by an internally discordant spectrum, sometimes saddle-, hump-, or crankshaft-shaped, or by a clustering or positive correlation between ${ }^{39} \mathrm{Ar} /{ }^{40} \mathrm{Ar}$ and ${ }^{36} \mathrm{Ar} /{ }^{40} \mathrm{Ar}$ isotopic ratios (rather than the expected negative correlation). Some of these samples with negatively correlated ${ }^{39} \mathrm{Ar} /{ }^{40} \mathrm{Ar}$ and ${ }^{36} \mathrm{Ar} /{ }^{40} \mathrm{Ar}$ ratios can be fit well with an isochron (Figure 5). For these samples we quote the isochron age, which takes into account the nonatmospheric ${ }^{40} \mathrm{Ar} /{ }^{36} \mathrm{Ar}$ ratio. Other samples have poorly correlated isotopic ratios that cannot be fit well with isochrons.

The only Triassic sample analyzed, $0177 \mathrm{a}$, yielded a concave-downward spectrum (Figure 6). The first four heating steps have a weighted mean age of $97.7 \mathrm{Ma}$, and steps 14-16 define an isochron of $214 \mathrm{Ma}$. The geologic significance of this spectrum is discussed later.

Three K-feldspar samples were analyzed using cyclic heating and cooling schedules over 3 days in the hope of obtaining cooling histories from domain analysis [Lovera et al., 1989]. However, the spectra (Figure 7) were judged unsuitable.

\section{Geologic Interpretation}

\section{Plagiogranites, Gabbros, and Hornblende Veins}

Plagiogranites intrude the isotropic gabbro, layered cumulate gabbro and peridotite, and harzburgite tectonite. Three of our samples (G225, H29-1, and P-700) were taken from plagiogranites where zircons had been previously dated by the U/Pb method as $94.6,95.4$, and $93.5 \pm 0.25$ Ma [Tilton et al., 1981]. Our other two samples (O35 and O37) were collected from hornblende-bearing gabbros intruded by plagiogranites dated by Tilton et al. [1981] as 94.5 and $94.5 \pm 0.25 \mathrm{Ma}$ (their samples H30-1 and OU-1, respectively). Three of our hornblende samples (H29-1, P700, and O35) yielded ages of 93.6, 93.7, and 94.5 \pm 0.5 Ma. Hornblende from $\mathrm{O} 37$ contained uninterpretable excess $\mathrm{Ar}$, and pyroxene from $\mathrm{G} 225$ yielded a poorly constrained age of $92 \pm 26 \mathrm{Ma}$ that is compatible with the three hornblende ages.

Late gabbroic rocks intrude the sheeted dikes, isotropic gabbro, layered gabbro, and harzburgite tectonite. Both attempts to date these rocks were disappointing in that one (O178) yielded an uninterpretable spectrum, while the other (O175) produced low radiogenic yields and an imprecise isochron age of $96.3 \pm 1.3 \mathrm{Ma}$.

Hornblende veins in the layered cumulate peridotite and gabbro were sampled near Halmiliyah [Nehlig and Juteau, 

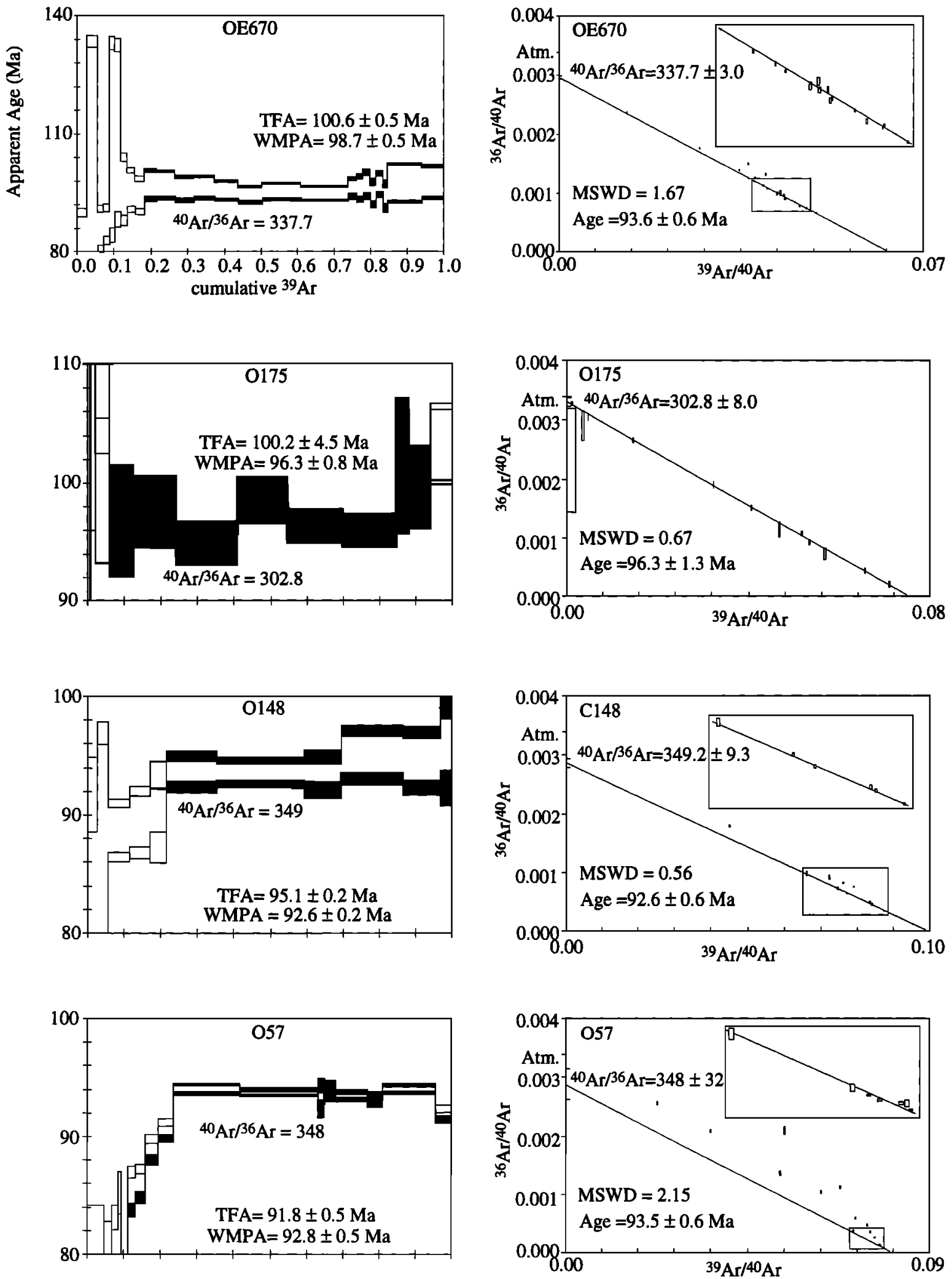

Figure 5. (Left) spectra and (right) inverse isochron diagrams for samples with interpretable excess 40Ar. MSWD: the mean square weighted deviation [Wendt and Carl, 1991], which expresses the goodness of fit of the isochron [Roddick, 1978]. Spectrum calculated assuming ${ }^{40 \mathrm{Ar} /}{ }^{36} \mathrm{Ar}=295.5$ shown with shaded boxes and spectrum calculated with ${ }^{40} \mathrm{Ar} /{ }^{36} \mathrm{Ar}$ intercept from isochron shown with solid boxes; WMPA refers to the latter. Inset in isotope correlation diagram shows expanded scale of data used to fit isochron. 


\section{A}
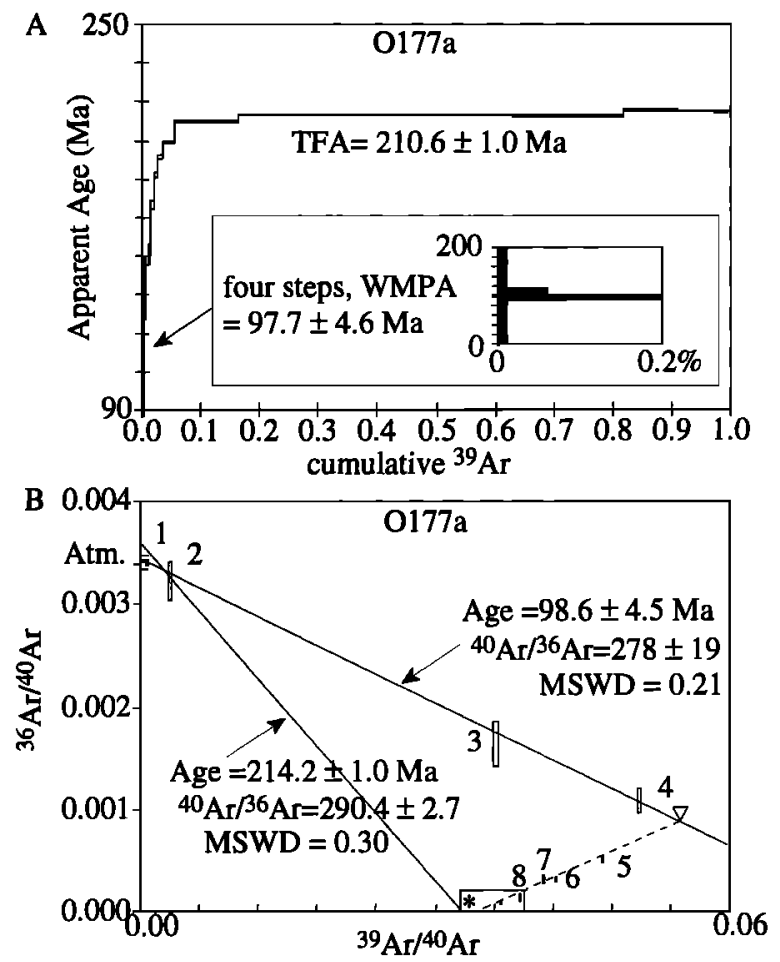

C

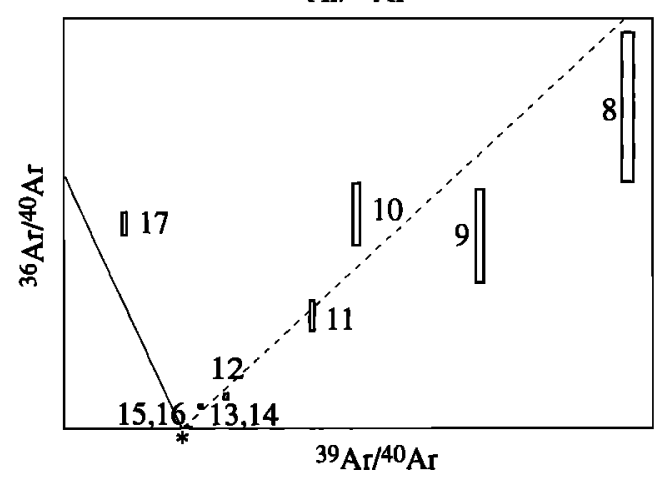

Figure 6. (a) Spectrum and (b) isotope correlation diagram for Haybi volcanics sample O177a. Inset in Figure 6a shows first $0.2 \%$ of ${ }^{39} \mathrm{Ar}$ released with a 4-step plateau age of $97.7 \mathrm{Ma}$. Isotope correlation diagram reveals two isochrons with mixing between atmosphere (Atm.) and a radiogenic component of $98.6 \mathrm{Ma}$ and between atmosphere and a radiogenic component of 214.2 Ma. Apparent mixing between $214 \mathrm{Ma}$ radiogenic component (asterisk) and an intermediate component along the $98.6 \mathrm{Ma}$ mixing line $(\nabla)$ is shown with a dotted line. (c) Expanded portion of Figure $6 \mathrm{~b}$ near ${ }^{36} \mathrm{Ar} /{ }^{40} \mathrm{Ar}$ axis. Successive heating steps are number sequentially in Figures $6 \mathrm{~b}$ and $6 \mathrm{c}$.

1988a, 1988b]. One sample (O171) was dated and gave an age of $95.4 \pm 0.5 \mathrm{Ma}$.

In aggregate, the ${ }^{40} \mathrm{Ar} /{ }^{39} \mathrm{Ar}$ ages we obtained on hornblendes from plagiogranites, upper level gabbros, latestage gabbros, and a hornblende vein range from $93.6 \pm 0.5$ $\mathrm{Ma}$ to $96.3 \pm 1.3 \mathrm{Ma}$ and are concordant at the $2 \sigma$ level. The weighted mean age is $94.4 \pm 0.3 \mathrm{Ma}$. This is indistinguishable at the $95 \%$ confidence interval from the mean plagiogranite zircon age of $94.8 \pm 0.1 \mathrm{Ma}$.

\section{Metamorphic Sole}

We dated 35 samples from the metamorphic sole, most of them from the two best described localities: Wadi Sumeini and Wadi Tayin. The hornblende samples come exclusively from amphibolite-facies mafic tectonite. Several samples (O11, O32, O33, 056, 073) gave uninterpretable spectra. Sixteen samples (O05, 016, O19, O21, O25, O57, O68, O127, C142, O146, C147, C148, OE657, OE670, OE672, OE721) yielded plateau or clearly interpretable isochron ages ranging from $92.6 \pm 0.6$ to 95.7 $\pm 0.3 \mathrm{Ma}$. These 16 ages have a weighted mean of $94.0 \mathrm{Ma}$, but are not externally concordant at 2 standard deviations.

The largest number of hornblende samples comes from Wadi Tayin in the southern part of the ophiolite. Although these 10 samples range in age from $92.6 \pm 0.6$ to $94.9 \pm 0.5$ $\mathrm{Ma}$, they do not show a consistent relationship between their age and their structural position or metamorphic grade within the metamorphic sole. They are very nearly externally concordant (within 0.1 m.y.) at the $95 \%$
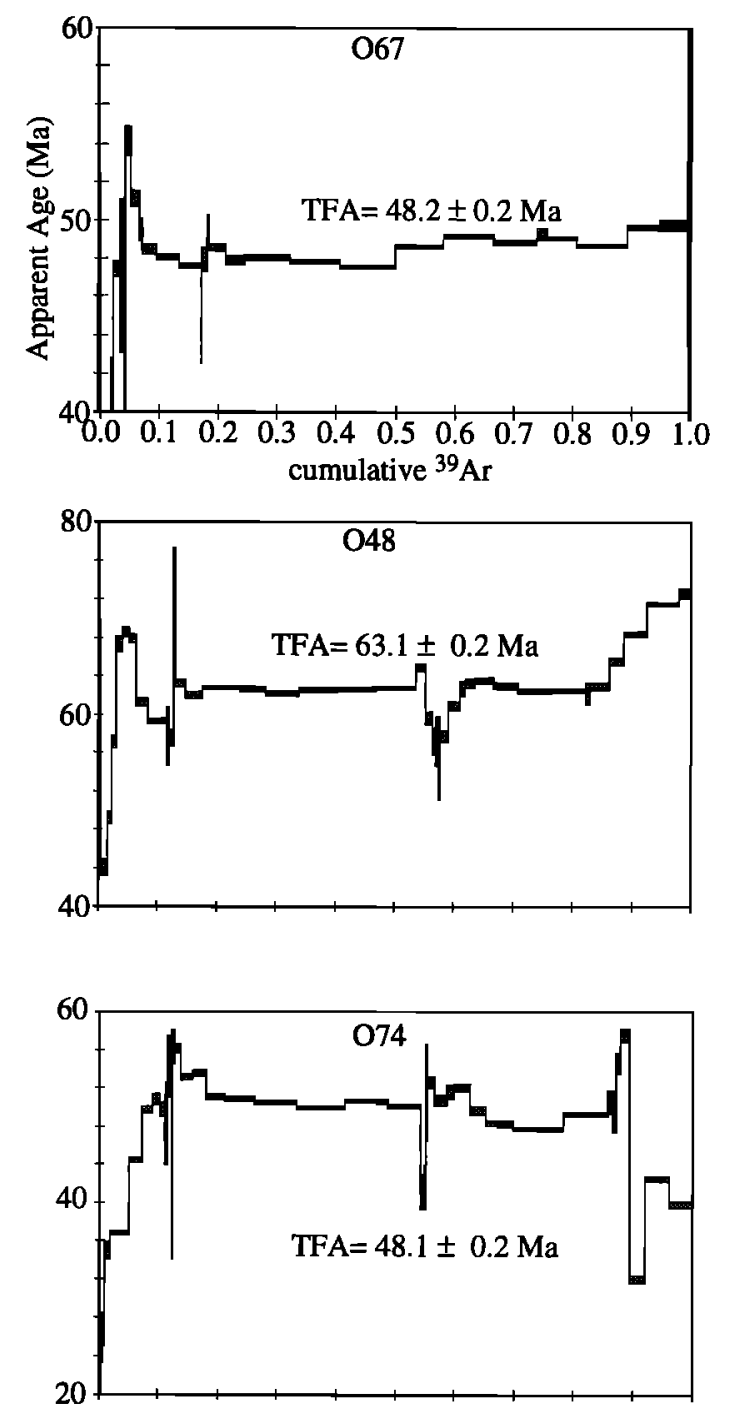

Figure 7. K-feldspar apparent age spectra. 
confidence interval, with a weighted mean age of $93.5 \pm 0.1$ Ma. The remaining six hornblendes from the metamorphic sole are from the northern part of the ophiolite and yield a significantly older age of $94.9 \pm 0.2 \mathrm{Ma}$.

White mica samples were obtained from phyllitic micabearing metacherts and calc-silicates at nine separate localities of the metamorphic sole. Their ages range from 90.9 to $93.6 \pm 0.5 \mathrm{Ma}$ and are externally discordant. Four ages (O01, O10, O13, O141) from Wadi Tayin span 91.8 to $93.6 \pm 0.5 \mathrm{Ma}$. These ages are externally concordant and have a weighted mean of $92.4 \pm 0.2 \mathrm{Ma}$. The remaining five samples (O40, O45, O65, OE996, OE1007, OE1016) from the northern part of the ophiolite are externally discordant and their weighted mean age is $92.7 \pm 0.2 \mathrm{Ma}$. Many biotites previously analyzed from the Oman ophiolite gave unusually young K/Ar ages [e.g., Gnos and Peters, 1993]. All the biotites we analyzed gave uninterpretable spectra with generally low total fusion ages.

The three K-feldspar ages, one of 63 Ma (Early Paleocene) and two of $48 \mathrm{Ma}$ (Middle Eocene) may be related to post-emplacement tectonic events in Oman. Folding and local cleavage development occurred throughout the Oman Mountains in the latest Maastrichtian-Early Paleocene (68-64 Ma) [Rabu, 1993].

\section{Diabase Dikes}

Diabase dikes intrude the metamorphic sole and the harzburgite tectonite [Gregory, 1984; Pallister and Hopson, 1981]. Most of the samples we collected were unsuitable for dating by the ${ }^{40} \mathrm{Ar} /{ }^{39} \mathrm{Ar}$ method because of alteration or fine grain size. However, hornblende from one sample gave an internally concordant age of $93.7 \pm 0.8 \mathrm{Ma}$. This sample (0161a) came from a 2-m thick diabase dike cutting peridotite and amphibolite in the Hammah window. The dike contains igneous plagioclase, magnesiohornblende, clinopyroxene, and magnetite. The dike truncates the high temperature foliation of the metamorphic sole produced at temperatures $\geq 775 \mathrm{~K}$, but shares a static greenschist-facies overprint (albite + epidote + chlorite + sphene) with the sole. A similar dike described by Pallister [1990] gave a ${ }^{40} \mathrm{Ar} /{ }^{39} \mathrm{Ar}$ total fusion age of $94.7 \pm 12.2 \mathrm{Ma}$ (M. Lanphere, personal communication, 1992).

\section{Late-Stage Granite and Diorite}

We studied several granite localities because a $\mathrm{K} / \mathrm{Ar}$ biotite age on one of these rocks of $85 \pm 3 \mathrm{Ma}$ [Lippard et $a l ., 1986]$ implies that the granite was emplaced $10 \mathrm{~m} . y$. after the ophiolite tormed. A composite granite and gabbro body intrudes serpentinized harzburgite and wehrlite WNW of Samad a few hundred meters below the igneous peridotite and gabbro [Gramont et al., 1986]. The granite (O162b) consists of hornblende, intermediate plagioclase, K-feldspar, biotite, quartz, and zircon; the gabbro (O163) contains plagioclase, quartz, and hornblende. The intrusive rocks are boudins within serpentinite that does not exhibit contact metamorphism. Rodingite formed between the gabbroic stock and ultramafic rock, particularly in the strain shadows between boudins. These relationships suggest that the granite and gabbro intruded the ultramafic rock, were boudinaged, and then rodingitized. Hornblende from the granite yielded a poorly constrained isochron, but the gabbro produced a flat spectrum with a weighted mean age of $94.1 \pm 0.5 \mathrm{Ma}$. A similarly deformed diorite (F339), also part of the wehrlitic suite [Gnos and Peters, 1993] intruding peridotite in Wadi Hayl, gave a hornblende age of $93.3 \pm$ $0.5 \mathrm{Ma}$. Near Halmiliyah a granitic dike (0168) cuts harzburgite and cumulate layered gabbro and ultramafic rocks [Beurrier et al., 1986]. Hornblende from this dike gave an age of $94.1 \pm 0.5 \mathrm{Ma}$. The mean age of these three externally concordant samples is $93.8 \pm 0.2 \mathrm{Ma}$.

White micas from garnet-bearing granites were also dated. Lepidolite from a weakly deformed stock intruding peridotite in Jabal Ghufayyil Khun (F252) [Gnos and Peters, 1993] yielded an age of $89.1 \pm 0.4 \mathrm{Ma}$, and muscovite from a weakly deformed stock intruding the metamorphic rocks in the Bani Hamid area (OE731) [Gnos and Peters, 1993] gave an age of $89.9 \pm 0.4 \mathrm{Ma}$.

Thus, the three hornblende ages from this late intrusive suite are indistinguishable from the hornblende ages from the metamorphic sole and the crustal plutonic sequence. The muscovite ages correspond to the younger muscovites of the metamorphic sole.

\section{Haybi Volcanics}

Lippard and Rex [1982] dated 14 alkalic rocks within the Hawasina and Haybi Complexes, including tuff and ankaramite blocks in melange, and dikes and sills intruding Upper Triassic limestone and the Haybi volcanics. They obtained K/Ar biotite ages ranging from $92 \pm 4$ to $233 \pm 9$ Ma, which led them to suggest that alkaline magmatism occurred episodically over a 140 m.y. time interval along the passive Oman margin [Lippard and Rex, 1982; Searle, 1984]. We dated amphibole from two outcrops of the Haybi volcanics. Alkaline tuff beneath the metamorphic sole in the Wadi Khurush area contains cogenetic hornblendite xenoliths. Hornblende from one xenolith (OE682) gave an age of 92.3 $\pm 0.5 \mathrm{Ma}$. Alleman and Peters [1972] published a biotite $\mathrm{K} / \mathrm{Ar}$ age of $94.2 \pm 6 \mathrm{Ma}$ (recalculated) from this same outcrop, and recovered Cenomanian-Turonian fossils from intercalated sedimentary rocks.

The second separate from the Haybi volcanics is kaersutite from a sill (O177a) at Jebel Ghawil that also contains titanaugite, biotite, plagioclase, allanite, sphene, and magnetite; alteration minerals include chlorite, albite, and zeolites. The spectrum (Figure 6) is concave downward and may represent Ar loss. The concave-downward shape of the initial part of the spectrum suggests that the age obtained from the final three concordant high-temperature steps, $214.1 \pm 1.0 \mathrm{Ma}$, is a minimum crystallization age. The first four low-temperature steps, which contain $0.2 \%$ of the total ${ }^{39} \mathrm{Ar}$, are internally concordant and yield a weighted mean age of $97.7 \pm 4.6 \mathrm{Ma}$. This single spectrum has notable implications. We equate the $97.7 \pm 4.6 \mathrm{Ma}$ portion of the spectrum with reheating associated with ophiolite emplacement at 94-95 Ma. The loss of ${ }^{40} \mathrm{Ar}$ from kaersutite implies that biotite, with its lower closure temperature, should be even more affected. Indeed, K-Ar 
ages on biotites from this rock are $92 \pm 4$ and $93 \pm 5 \mathrm{Ma}$ [Lippard and Rex, 1982]. Rather than reflecting volcanism at c. 92 Ma [Lippard and Rex, 1982], these biotite ages likely result from resetting during ophiolite emplacement. Significantly, the only samples that Lippard and Rex [1992, p. 502] described as "glassy rocks with...no sign of reaction or alteration," gave K/Ar biotite ages of $216 \pm 8,220 \pm 8$, $223 \pm 8$, and $233 \pm 9 \mathrm{Ma}$. These biotite ages, in conjunction with our minimum age of $214 \pm 1 \mathrm{Ma}$, suggest that the crystallization ages of these alkaline rocks is $\sim 220 \mathrm{Ma}$. Thus, the Haybi volcanics were erupted at $\sim 220$ and $92 \mathrm{Ma}$ and metamorphosed at 94-95 Ma; intermediate $\mathrm{K} / \mathrm{Ar}$ biotite ages of 129 and $\sim 160 \mathrm{Ma}$ [Lippard and Rex, 1982] may be geologically meaningless.

\section{Discussion}

The following discussion is predicated on three assumptions. (1) The plagiogranite zircon ages date the formation of Samail oceanic crust. (2) The ages of the metamorphic sole reflect single-stage cooling, not a reheating event following initial metamorphism. (3) The metamorphic sole and igneous crust are not unrelated, juxtaposed thrust sheets. The latter is a good assumption because the post-peak metamorphic dikes that cut both the sole and the overlying plutonic rocks have ${ }^{40} \mathrm{Ar} /{ }^{39} \mathrm{Ar}$ hornblende ages indistinguishable from the sole, indicating that all these rocks shared a common cooling history. Assumption 2 is also justified because the steep inverted peak metamorphic temperature gradient in the sole requires that it was produced by active thrusting beneath a hot thrust sheet and cannot be the result of static metamorphism [Hacker, 1990].

Assumption 1 requires the most scrutiny. Plagiogranites in ophiolites have been interpreted as extreme differentiates of spreading center magmas, partial melts of rocks thrust beneath ophiolites, partial melts of hydrothermally altered oceanic dikes and gabbros, and off-axis magmas. Numerous authors have concluded that the Samail plagiogranites are late-stage differentiates of the magmas that formed most of the plutonic section [Juteau et al., 1988; Lippard et al., 1986; Reuber, 1988; Tilton et al., 1981]. Moreover, the U/Pb plagiogranite ages are concordant with the fossil ages of the lower and middle volcanic rocks of the ophiolite. Radiolarians in the lowest part of the V1 volcanics are Cenomanian (98.9-93.5 Ma) [Tippit et al., 1981], matching precisely the 97.3 to $93.5 \pm$ $0.25 \mathrm{Ma}$ zircon ages. One plagiogranite (sample WJ5-1) believed to be part of the wehrlitic magma series that intruded the gabbroic series, gave a zircon age of $94.8 \mathrm{Ma}$, which lies in the middle of the range obtained for plagiogranites from the gabbroic series [Tilton et al., 1981]. This age implies that the bulk of the crust is $\sim 95 \mathrm{Ma}$. However, it is possible that the field relationships have been misinterpreted, that the 11 plagiogranites with zircon ages $\leq 95.4$ Ma come from the wehrlitic suite and that the 96.9 and 97.3 Ma plagiogranites are part of the gabbroic suite. At the extreme, the oldest crust in the Samail ophiolite might be $\sim 97 \mathrm{Ma}$, rather than $\sim 95 \mathrm{Ma}$.

\section{Summary of Age Relationships}

Most of the dated plagiogranites in the ophiolite crystallized between 95.4 and $94.5 \pm 0.5 \mathrm{Ma}$ [Tilton et al., 1981 ], with a mean age of $94.8 \mathrm{Ma} \pm 0.08 \mathrm{Ma}$ (Figure 3). Hornblendes from these plagiogranites, gabbros, and veins in peridotite gave ages of $93.6 \pm 0.5 \mathrm{Ma}$ to $96.3 \pm 1.3 \mathrm{Ma}$ with a mean of $94.4 \pm 0.3 \mathrm{Ma}$. Granitic to dioritic stocks and dikes interpreted as the final magmas intruded into the upper mantle yielded hornblende ages of 93.3 to $94.1 \pm 0.5$ Ma with a mean of $93.8 \pm 0.28 \mathrm{Ma}$. Hornblendes from the metamorphic sole at Wadi Tayin range from $92.6 \pm 0.6$ to $94.9 \pm 0.5 \mathrm{Ma}$, with a mean of $93.5 \pm 0.1 \mathrm{Ma}$. Hornblendes from the sole in the northern part of the ophiolite span 92.6 \pm 0.6 to $95.7 \pm 0.3 \mathrm{Ma}$, with a mean of $94.9 \pm 0.2 \mathrm{Ma}$. These ${ }^{40} \mathrm{Ar} /{ }^{39} \mathrm{Ar}$ hornblende ages are concordant with most pre-existing K/Ar hornblende ages [Allemann and Peters, 1972; Gnos and Peters, 1993; Lanphere, 1981; Lippard et al., 1986; Montigny et al., 1988; Searle et al., 1980] (Figure 3 ). We suggest that $\mathrm{K} / \mathrm{Ar}$ hornblende ages younger than $\sim 92.5 \mathrm{Ma}$ are from rocks that underwent Ar loss and that $\mathrm{K} / \mathrm{Ar}$ ages older than $\sim 95.5 \mathrm{Ma}$ reflect excess ${ }^{40} \mathrm{Ar}$, as documented for numerous samples in this study. Muscovite ages from the metamorphic sole range from 90.9 to $93.4 \pm$ $0.3 \mathrm{Ma}$, and have a weighted mean age of $92.4 \pm 0.2 \mathrm{Ma}$. Like the hornblende ages, published K/Ar muscovite ages [Allemann and Peters, 1972; Gnos and Peters, 1993] are concordant with our ${ }^{40} \mathrm{Ar} /{ }^{39} \mathrm{Ar}$ ages, except for a few outliers that may reflect $\mathrm{Ar}$ loss or excess ${ }^{40} \mathrm{Ar}$. Previously determined $\mathrm{K} / \mathrm{Ar}$ biotite ages span $85.5 \pm 5$ to $92.5 \pm 4 \mathrm{Ma}$ [Allemann and Peters, 1972; Gnos and Peters, 1993; Searle et al., 1980] with a weighted mean of $89.2 \pm 0.4 \mathrm{Ma}$. Thus, the zircon, hornblende, muscovite, and biotite ages are successively younger, as expected [McDougall and Harrison, 1988]. The dated diabase dike ( $93.7 \pm 0.8 \mathrm{Ma})$ that cuts the metamorphic sole postdates the predominant amphibolite-facies metamorphism and deformation of the sole, and predates minor greenschist-facies metamorphism and deformation at this locality.

\section{Cooling Rate}

The ${ }^{40} \mathrm{Ar} /{ }^{39} \mathrm{Ar}$ age of a mineral indicates the time that the mineral cooled through its effective closure temperature. Closure temperature depends on mineral composition, structural state, the path length for $\mathrm{Ar}$ diffusion, and cooling rate [Dodson, 1973]. Assuming a characteristic diffusion distance of $100 \mu \mathrm{m}$ and a cooling rate of $100 \mathrm{~K} / \mathrm{m}$.y. and using experimentally determined parameters for Ar diffusion from Harrison [1981], Robbins [1972], and Giletti [1974], we calculate closure temperatures of $825 \mathrm{~K}, 750 \mathrm{~K}$, and $720 \mathrm{~K}$ for hornblende, muscovite, and $\mathrm{Mg}$-rich biotite (biotites analyzed by Gnos [1992] are $\mathrm{Mg}$-rich). At a cooling rate of $10 \mathrm{~K} / \mathrm{m}$.y. the computed closure temperature for $\mathrm{Mg}$-rich biotite is $680 \mathrm{~K}$. If the plagiogranites crystallized at $\sim 975 \mathrm{~K}$ at $94.8 \mathrm{Ma}$ and the hornblendes in the crustal section closed to Ar diffusion at $\sim 825 \mathrm{~K}$ at $94.4 \mathrm{Ma}$, the cooling rate in the crust was $\sim 375$ $\mathrm{K} / \mathrm{m}$.y (Figure 8). This is entirely compatible with Morton and Sleep's thermal model of ocean ridges that considered convective hydrothermal cooling; they calculated that the 
HACKER ET AL.: RAPID EMPLACEMENT OF THE OMAN OPHIOLITE

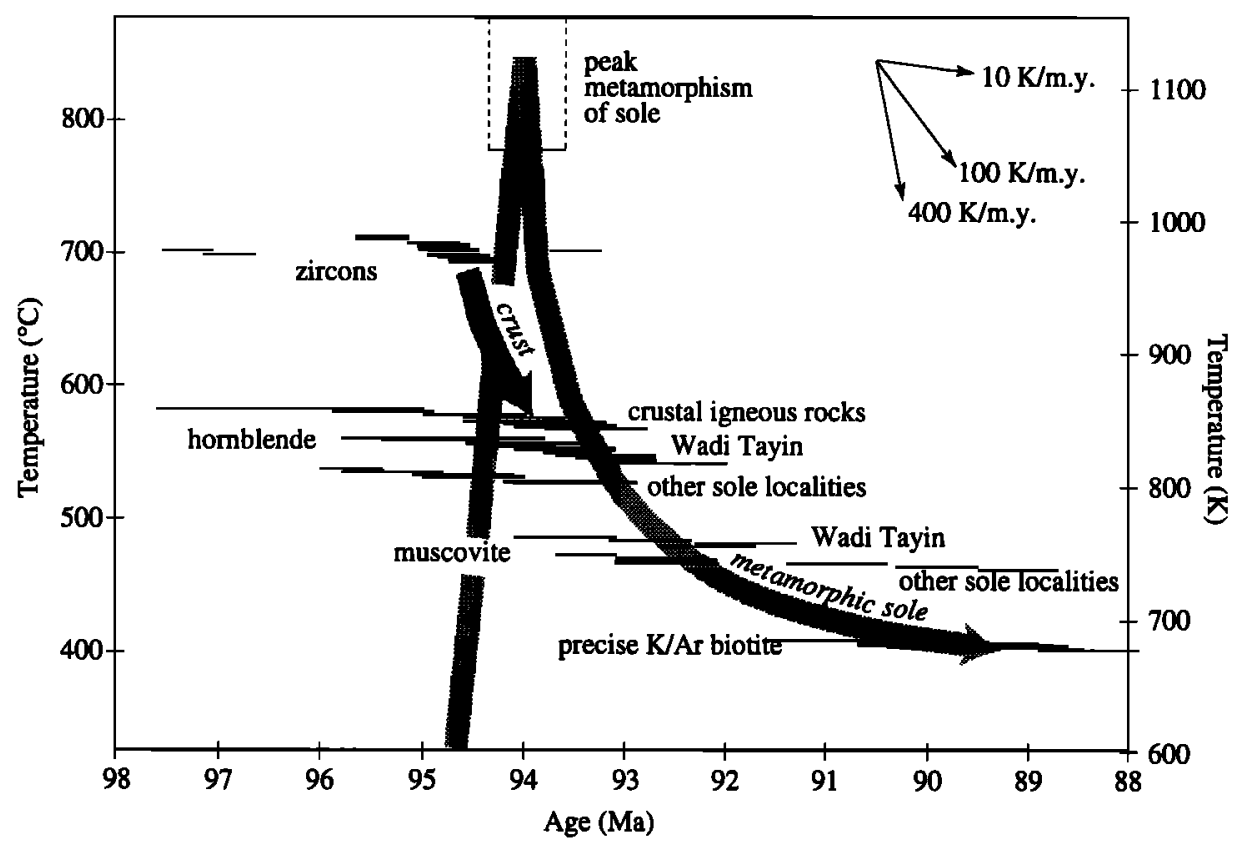

Figure 8. Thermal histories of the igneous crust and metamorphic sole in Oman. Crustal cooling is defined by zircon and hornblende. Sole cooling history is defined by the seafloor temperature of the initially subducted material ( $275 \mathrm{~K}$; offscale), peak metamorphic temperature (1050-1150 K), and hornblende, muscovite, and biotite cooling ages and closure temperatures.

upper levels of oceanic magma chambers in an EastPacific-Rise type spreading center cool below $825 \mathrm{~K}$ in 0.3-1.0 m.y. The peak temperature of the metamorphic sole was 1050-1150 K [Ghent and Stout, 1981; Searle and Malpas, 1980]; presumably this occurred after plagiogranite crystallization at $94.8 \mathrm{Ma}$. Cooling of the metamorphic sole hornblendes below $\sim 825 \mathrm{~K}$ before 93.5 Ma implies a cooling rate of $200 \mathrm{~K} / \mathrm{m}$.y. If the muscovites cooled below $\sim 750 \mathrm{~K}$ within an additional $0.9 \mathrm{~m} . \mathrm{y}$. and the biotites below $\sim 680 \mathrm{~K}$ within another $3.4 \mathrm{Ma}$, the cooling rate slowed initially to $\sim 90 \mathrm{~K} / \mathrm{m}$.y. and then further decreased to $\sim 20 \mathrm{~K} / \mathrm{m}$.y.

\section{Rate and Duration of Intraoceanic Thrusting}

Its size and shape suggest that the Samail thrust sheet comprising only the ophiolite (including its metamorphic sole) was displaced roughly $150 \mathrm{~km}$ over the underlying rocks. If this displacement was accommodated entirely as homogeneous simple shear within a 200-500 m thick metamorphic sole, then the shear strain of the sole is $\leq 300$ 750. This is a maximum because displacement of the ophiolite was also accommodated within the lowermost portion of the peridotite, within the rocks underlying the sole, and along the brittle fault at the base of the sole.

Two factors dictate that ductile deformation of the metamorphic sole lasted only 1-2 m.y. Deformation of the sole involved crystal plasticity of hornblende, which is believed to occur in nature at temperatures $\geq 725 \mathrm{~K}$ [Hacker and Christie, 1990]. Metamorphic mineral assemblages preserved in the sole indicate that penetrative deformation of the amphibolite occurred at temperatures of 775 to 1100 $\mathrm{K}$. The closure temperature for Ar diffusion in hornblende was $\sim 825 \mathrm{~K}$ (see above). Thus, crystal plastic deformation of hornblende in the sole occurred before Ar was trapped in the hornblende. More conclusively, the weakly deformed, greenschist-facies diabase dikes that cut the metamorphic sole indicate that amphibolite-facies deformation had ended within 1-2 m.y. of plagiogranite crystallization. If the ophiolite was thrust $150 \mathrm{~km}$ along the sole in 1-2 m.y., the slip rate was $75-150 \mathrm{~km} / \mathrm{m}$.y. If shear strains of $300-750$ were achieved within the metamorphic sole in 1-2 m.y., the shear strain rate was $-10^{-11} \mathrm{~s}^{-1}$.

Boudier et al. [1988] presented lineation and crystal lattice preferred orientation data from the metamorphic sole and from peridotite overlying the sole that they interpreted to indicate southward thrusting followed by westward thrusting. The bulk of their S-directed shear sense observations come from the northern $\sim 80 \%$ of the ophiolite, whereas their inferences of W-directed shear were derived chiefly from two massifs near Wadi Tayin (Figure 1). They used $\mathrm{K} / \mathrm{Ar}$ hornblende ages, some of which we have argued are unreliable [Hacker, 1994], to infer that the S- and Wdirected shear occurred from $\sim 101$ to $97 \mathrm{Ma}$ and $\sim 97$ to 90 $\mathrm{Ma}$, respectively. Our ${ }^{40} \mathrm{Ar} /{ }^{39} \mathrm{Ar}$ measurements reveal that their conclusions about relative timing are correct, but that based on the different ranges of hornblende ages we measured from the northern and southern parts of the ophiolite, southward thrusting was from 95.7 to $93.5 \mathrm{Ma}$ and westward motion from 94.9 to $92.6 \mathrm{Ma}$.

Paleomagnetic Euler poles calculated from magnetic signatures of the upper and middle lavas suggest that the Samail ophiolite rotated $\sim 150^{\circ}$ during the Cenomanian (98.9-93.5 Ma) [Perrin et al., 1994]. If the rotation was spread over the entire Cenomanian, the rotation rate was $30 \%$ m.y., and a $400-\mathrm{km}$ diameter plate rotating en masse 
would have had a tangential boundary velocity of $\geq 17$ $\mathrm{km} / \mathrm{m}$.y. However, if oceanic crust formation ended by 95.4-94.5 Ma (the plagiogranite ages), the rotation rate must have been $\sim 75-150 \%$ m.y., and the boundary velocity $\geq 83 \mathrm{~km} / \mathrm{m}$.y. These boundary velocities are minima because Perrin et al. [1994] have argued that the Euler pole was not located in the center of the Samail ophiolite.

\section{Rate and Duration of Subsequent Thrusting}

Good constraints have been placed on the end of the emplacement process, which is signaled by the first appearance of igneous detritus on the Arabian craton in the Mid to Late Campanian (78-71 Ma) Juweiza Formation [Rabu, 1993; Warburton et al., 1990]. Thus, after the 994 $93 \mathrm{Ma}$ intraoceanic thrusting along the metamorphic sole and before the arrival of the ophiolite on the continent by $\sim 78 \mathrm{Ma}$, the ophiolite traveled another $250-350 \mathrm{~km}$ over basin, slope, and shelf deposits [Bechennec et al., 1988, 1990] and $150 \mathrm{~km}$ over the continent, borne by deeper level thrust sheets, at an average rate of $\sim 25-33 \mathrm{~km} / \mathrm{m}$.y.

\section{Buoyancy Effects}

Davies [1992] showed that Phanerozoic oceanic lithosphere younger than $\sim 20-40 \mathrm{Ma}$ was more buoyant than average mantle material and could not sink even when overlain by asthenosphere, whereas lithosphere older than 20-40 Ma was cold and dense enough to sink. The Samail ophiolite was less than $20 \mathrm{~m}$.y. old at the time of intraoceanic thrusting and thus its preservation was linked fundamentally to its positive buoyancy.

As mentioned above, Boudier et al. [1988] inferred that the intraoceanic thrusting was initially southward but was followed by westward motion. If these episodes of different thrusting direction were separated by $>6 \mathrm{~m}$.y., one could argue that substantial changes in the buoyancy of the lithospheric plates relative to the asthenosphere caused the changes in direction. Demonstration that these events encompassed 1-2 m.y. in toto rules out this possibility and suggests that the changes in direction are related to local peculiarities in plate geometry or changes in far-field stresses.

\section{Were All Tethyan-Type Ophiolites Young During Thrusting?}

Preservation of the Samail ophiolite was likely the direct result of its young age and positive buoyancy relative to mantle asthenosphere. If this reasoning is extended beyond the Samail ophiolite, other Phanerozoic Tethyan-type ophiolites generated at spreading centers may also have been younger than $20-40 \mathrm{~m}$.y. old at the time intraoceanic thrusting began. Ophiolites formed in mature arcs or other settings and ophiolites in accretionary wedges (Cordillerantype ophiolites of Moores [1982]) were likely emplaced by a different mechanism and may never have undergone intraoceanic thrusting of the type envisaged for the Samail ophiolite.

The few detailed geochronologic studies report that the time between crustal crystallization and intraoceanic thrusting in ophiolites is perhaps as much as $\mathbf{2 0}$ m.y. For example, Wirth et al. [1993] reported $25{ }^{40} \mathrm{Ar} /{ }^{39} \mathrm{Ar}$ ages from two ophiolites emplaced onto a passive margin in the western Brooks Range, Alaska. They dated crustal igneous rocks and metamorphic sole rocks, and interpreted the ages to indicate igneous crystallization from 187 to $184 \mathrm{Ma}$ and sole formation from 169 to $163 \mathrm{Ma}$. We propose a different interpretation of their data, considering only their 14 hornblende ages, which by virtue of their high closure temperature most closely approximate igneous crystallization and emplacement ages. Their hornblende samples can be divided into three groups of decreasing ease of interpretation: (1) five samples with plateau or nearplateau ages; (2) four with complex spectra interpreted by Wirth et al. [1993] to be the result of degassing of a single Ar reservoir, but yielding large (i.e., poor) MSWD (goodness of fit) values; and (3) five samples with complex spectra interpreted by Wirth et al. [1993] to be the result of degassing of two Ar reservoirs. If we exclude the nine samples with poorly constrained isochrons and consider only the plateau and near-plateau ages, two igneous crustal ages of $163.1 \pm 2.8$ and $168.8 \pm 1.9 \mathrm{Ma}$ and three metamorphic ages of $164.9 \pm 0.6,168.1 \pm 1.2$, and $168.1 \pm$ 1.2 Ma remain. This conservative reinterpretation of Wirth et al.'s [1993] data reveals that the age of igneous crystallization and the time of sole metamorphism are indistinguishable. Geochronologic investigation of other well-known ophiolites, such as the Bay of Islands, Newfoundland, could test our hypothesis that other ophiolites generated at spreading centers were young at the time intraoceanic thrusting initiated.

\section{Mechanism of Ophiolite Emplacement}

There are three possible scenarios for formation of the Samail metamorphic sole by intraoceanic thrusting (Figure 9): (1) the ophiolite represents the eastern limb (present coordinates) of a spreading center and was thrust over the western limb along a fault that began at the spreading center [Boudier et al., 1985]; (2) the ophiolite represents

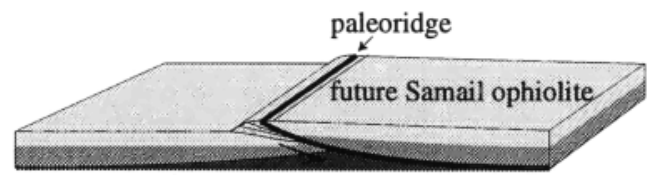

A) eastern flank of spreading center thrust over opposite flank

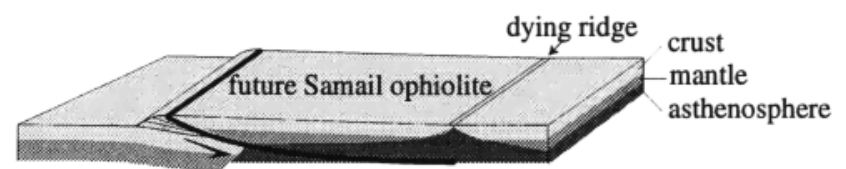

B) western flank of spreading center thrust over same flank

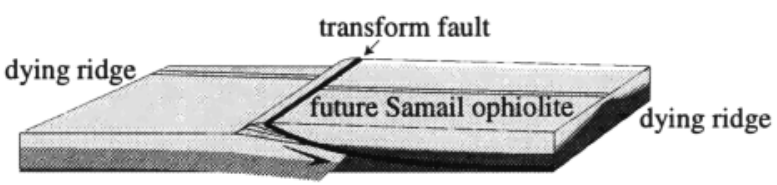

C) spreading center thrust across a transform fault

Figure 9. Proposed tectonic settings for intraoceanic thrusting of the Samail ophiolite. 
the western limb of a spreading center and was thrust over older lithosphere also on the western side [Lippard et al., 1986]; (3) the ophiolite represents either or both limbs of a spreading center and was thrust parallel to the spreading axis [Boudier et al., 1988].

If the ophiolite represents $200 \mathrm{~km}$ from one limb of a spreading center, the spreading rate dictates the range of zircon crystallization ages of the crust. For example, if the spreading rate was $50 \mathrm{~mm} / \mathrm{yr}$, ages across the $200-\mathrm{km}$ wide ophiolite should span 4 m.y. (Figure 10). Likewise, the rate of intraoceanic thrusting dictates the minimum duration of metamorphic sole formation. For instance, if the intraoceanic thrusting rate was $100 \mathrm{~km} / \mathrm{m} . \mathrm{y} ., 2 \mathrm{~m} . \mathrm{y}$. would be required for the sole to form beneath the entire ophiolite. Different geometries for intraoceanic thrusting yield different relationships among (1) the crustal age range, (2) the sole age range, and (3) the difference between the two ages at any particular place within the ophiolite (Figure 10). (1) Tilton et al. [1981] proposed that the small variation in zircon ages across the ophiolite indicates a spreading rate of $>65-100 \mathrm{~mm} / \mathrm{yr}$ (2) The 1-2 m.y. span in hornblende cooling ages from the sole implies that the thrusting rate was $~ 100-200 \mathrm{~mm} / \mathrm{yr}$ (Figure 10). (3) The 1-2 m.y. interval between zircon crystallization ages and hornblende cooling ages from the sole is most compatible with thrusting of the ophiolite away from a more easterly ridge or parallel to a ridge (asterisks in Figure 10), and least compatible with thrusting over a more westerly ridge. This is a particularly crucial constraint. If thrusting began at 95 Ma at $200 \mathrm{~km} / \mathrm{m}$.y., then the metamorphic sole could have been established across the $200 \mathrm{~km}$ base of the ophiolite by $94 \mathrm{Ma}$. If thrusting of cold material then began at the same rate, the metamorphic sole could have cooled by $93 \mathrm{Ma}$. Thrusting rates any slower than this do not solve the tight constraints provided by the zircon and hornblende ages. Moreover, this approach uses ohly the minimum, $200 \mathrm{~km}$, dimension of the ophiolite. In reality, the ophiolite is 300 $400 \mathrm{~km}$ long parallel to its paleoridge, and if thrusting was initially parallel to the ridge, as suggested by Boudier et al. [1988], the thrusting must have been even faster. Paleomagnetic and structural data support the suggestion that the ophiolite represents one or both limbs of a spreading ridge thrust initially southward parallel to the ridge axis.

The high peak metamorphic temperatures in the sole of $1100 \mathrm{~K}$ [Ghent and Stout, 1981; Searle and Malpas, 1980] and the rapid cooling documented here place two powerful constraints on the mechanism of ophiolite emplacement that are difficult to satisfy. First, the peak temperature of the metamorphic sole reached $\sim 1100 \mathrm{~K}$ after zircons crystallized in the oceanic crust but before hornblendes closed to Ar diffusion ( $~ 830 \mathrm{~K})$. Second, the hornblendes cooled below $\sim 830 \mathrm{~K}$ within 1-2 m.y. after the zircons crystallized.

One-dimensional consideration of heat flow at constant thermal diffusivity illustrates the power of these constraints. If two parallel and identical plates of different temperature are placed in contact, the temperature at the contact is the mean of the two temperatures. At any later time $t$, the thermal effect of one plate on the other will have progressed a characteristic diffusion distance $u=2 \sqrt{\mathrm{kt}}$, where $K$ is the thermal diffusivity. A corollary to this is that a temperature gradient in one plate can affect the temperature of the contact only if at time $t$ the gradient is within distance $u$ of the contact. The thermal diffusivity of most rocks is $\sim 1 \mathrm{~mm}^{2} / \mathrm{s}$, such that $u \sim 10-15 \mathrm{~km}$ for $t=1-2$ m.y.

The highest temperature rocks in the metamorphic sole formed at roughly $15-25 \mathrm{~km}$ depth [Ghent and Stout, 1981; Searle and Malpas, 1980]. The temperature at $15 \mathrm{~km}$ depth in 1- and 5-m.y.-old oceanic material is $\sim 1500$ and $1075 \mathrm{~K}$ [Parsons and Sclater, 1977]. For the peak temperature of the metamorphic sole at the base of a 1-m.y.-old upper plate to have reached $\sim 1100 \mathrm{~K}$, the lower plate must have been at least as warm as $\mathrm{T}=(2 \times 1100)-1500=700 \mathrm{~K}$. Similar reasoning indicates that the top of the lower plate must have

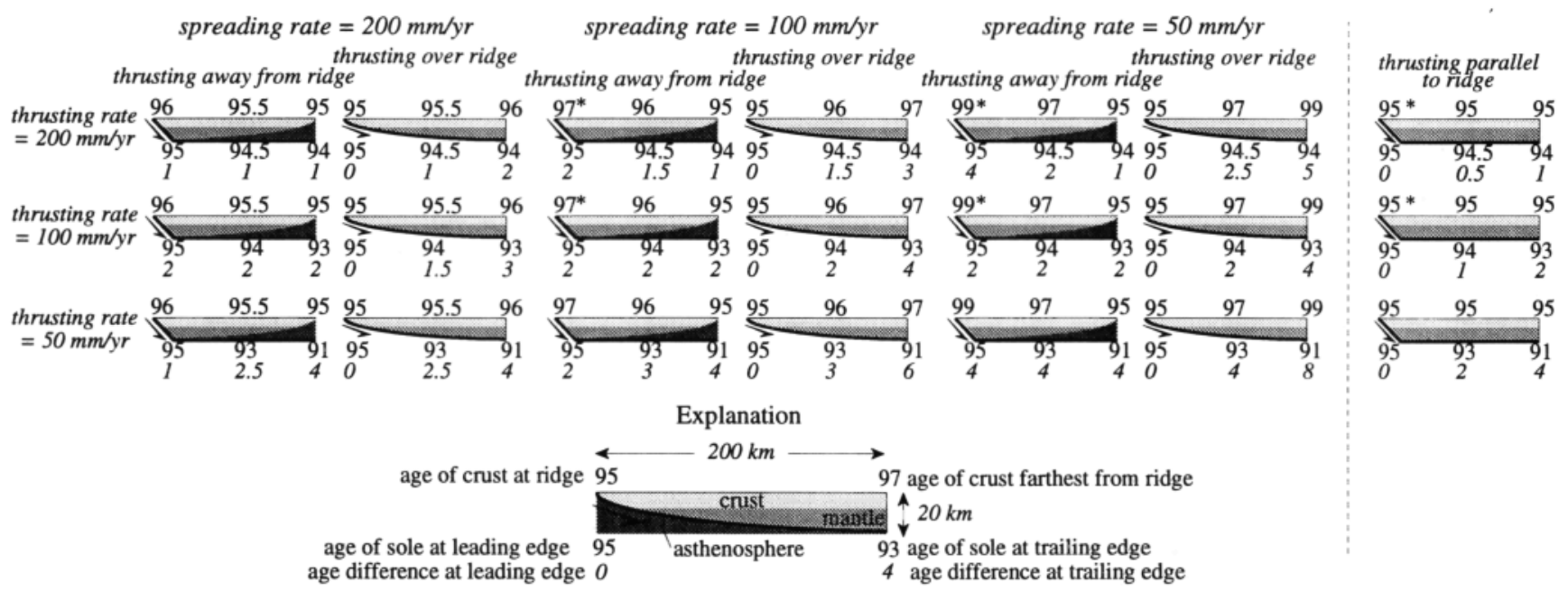

Figure 10. Geometric relationships between spreading rate and direction and thrusting rate and direction produce specific age gradient patterns within the crust and metamorphic sole. In every case the assumed time of intraoceanic thrusting is $95 \mathrm{Ma}$. Asterisks indicate scenarios that most closely fit geochronological constraints. 
been at $T=(2 \times 1100)-1075=1125 \mathrm{~K}$ to obtain temperatures of $1100 \mathrm{~K}$ at the base of an ophiolite that was $5 \mathrm{~m} . \mathrm{y}$. old. Because the metamorphic sole contains metasedimentary rock, it is commonly assumed that the plate subducted beneath the Samail ophiolite had oceanic sediments on top. Thus its surface temperature was $\sim 275 \mathrm{~K}$, much less than 700 or $1125 \mathrm{~K}$. The upper part of the subducting plate must have warmed to $700 \mathrm{~K}$ during thrusting beneath the ophiolite by deformational heating and conduction of heat from the hot 1-m.y.-old hanging wall. Though illustrative, this one-dimensional consideration of two plates placed in contact instantaneously is far removed from the actual geologic situation under consideration, particularly in neglecting heat advection, variations in thermal diffusivity, heat sources and heat sinks. However, two-dimensional thermomechanical simulations of Samail ophiolite thrusting [Hacker, 1991], also indicate that in order for peak temperatures of $1100 \mathrm{~K}$ to have obtained within $1 \mathrm{~m} . \mathrm{y}$., the ophiolite must have been less than $2 \mathrm{~m} . \mathrm{y}$. old at the time of intraoceanic thrusting.

The one-dimensional considerations outlined above can also be applied to the second constraint: that the metamorphic sole cooled below $\sim 830 \mathrm{~K}$ within $\sim 1-2 \mathrm{~m}$.y. after the zircons crystallized. Not only must the thermal regime have been hot enough to sustain $1100 \mathrm{~K}$ long enough for basaltic material to have been subducted to 15$25 \mathrm{~km}$ beneath the entire $200 \mathrm{~km}$ width of the ophiolite, but it must subsequently have become cold enough to reduce the temperature below $830 \mathrm{~K}$ in $1-2 \mathrm{~m} . \mathrm{y}$. If the sole temperature was $1100 \mathrm{~K}$ the sole must have come in contact with a lower plate at a temperature of $T=(2 \times 830)-1100$ $=560 \mathrm{~K}$. This marked decrease in metamorphic sole temperature in such a short time requires that the lower plate cooled dramatically. For example, in thermomechanical simulations using subduction of 2-m.y.old lithosphere, the sole remains above $830 \mathrm{~K}$ for $9 \mathrm{~m} . \mathrm{y}$.

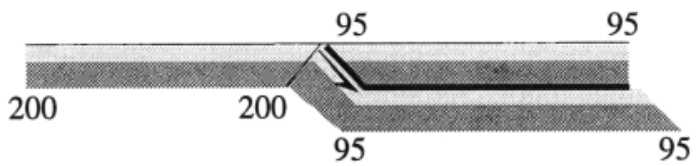

A. change in subducted plate age

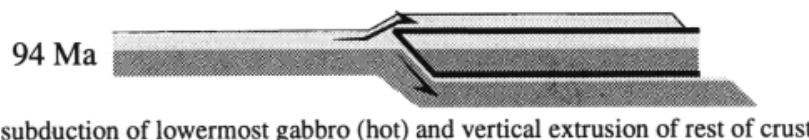

$93 \mathrm{Ma}$

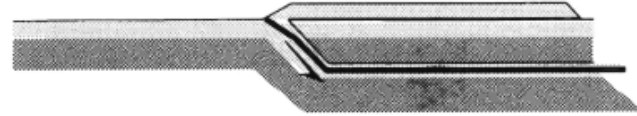

subduction of entire crust (cold)

B. change in decollement level

Figure 11. Possible means by which the temperature of the lower plate could change suddenly. a) Plate age changes; b) decollement level changes from within a hot central portion of the lower plate to the cold upper surface of the lower plate. after the beginning of thrusting [Hacker, 1991]. Two attractive mechanisms by which the lower plate might suddenly have changed temperature are a change in lower plate age or a change in depth of the thrust decollement (Figure 11).

Lippard et al. [1986] suggested that the Samail ophiolite formed as a suprasubduction-zone rift within oceanic lithosphere already aged $10-100 \mathrm{~m} . \mathrm{y}$. On the basis of the trace-element match between the metamorphic sole and the 150 Ma Masirah ophiolite farther south in Oman, and Neocomian (144-122 Ma) chert and limestone immediately beneath the sole, Rabu [1993] proposed that the Samail ophiolite was thrust over oceanic lithosphere that was 50 m.y. old at the time of thrusting. We would modify these suggestions to propose that the ophiolite was thrust parallel to a spreading ridge at near $150 \mathrm{~mm} / \mathrm{yr}$ for $1-2 \mathrm{~m}$.y. and then thrust over $50-\mathrm{m}$.y.-old lithosphere at a similar rate for $\geq 1$ m.y.

\section{Conclusions}

The bulk of igneous crust in the Samail ophiolite crystallized between 95.4 and $94.5 \pm 0.5 \mathrm{Ma}$. Hornblende ${ }^{40} \mathrm{Ar} /{ }^{39} \mathrm{Ar}$ ages on a wide variety of rocks from the crustal section indicate cooling to $\sim 825 \mathrm{~K}$ by $\sim 93.8 \mathrm{Ma}$. Hornblendes from the metamorphic sole show cooling to equivalent temperatures by $\sim 93.5 \mathrm{Ma}$. Muscovite and biotite ages of 92.4 and $\sim 89.2 \mathrm{Ma}$ indicate cooling of the sole below $680 \mathrm{~K}$ at $<100 \mathrm{~K} / \mathrm{m}$.y. A diabase dike that cuts the metamorphic sole has a hornblende age of $\sim 93.7 \mathrm{Ma}$, confirming the end of amphibolite-facies metamorphism and deformation of the sole.

Our favored scenario is as follows (Figure 12): The ophiolite formed within predominantly 50-m.y.-old lithosphere. Forced closure of the ocean basin caused thrusting of young lithosphere over older lithosphere along transform faults. Transform faults are favored sites for intraoceanic thrusting because they juxtapose young, buoyant, topographically elevated lithosphere against older, denser, more subsided lithosphere; faulting along an intrusive contact between young and old lithosphere is also possible, but less likely. If the ophiolite formed within 50m.y.-old lithosphere, the transform faults could juxtapose lithosphere with large age and density contrasts but little strike-slip offset. Ernewein et al. [1988] have argued that the late, wehrlitic plutonic series was intruded during the transition from normal spreading to contraction; this is favored in our proposed scenario by continued extension orthogonal to the ridge. The first phase of intraoceanic thrusting carried the Samail ophiolite over young (<2-m.y.old) lithosphere at $150 \mathrm{~km} / \mathrm{m}$.y. parallel to a spreading ridge for 1-2 m.y. This was the time of peak sole metamorphism and cooling of the crustal section of the ophiolite. The second phase was equally rapid and brief thrusting over old and cold lithosphere, during which the metamorphic sole underwent rapid, substantial cooling. Emplacement of the ophiolite onto the continent occurred by $\sim 78 \mathrm{Ma}$ after another $400-500 \mathrm{~km}$ of travel at $\sim 25-33 \mathrm{~km} / \mathrm{m}$.y.

Preservation of the Samail ophiolite is the direct result of its young age and positive buoyancy at the time of ocean closure. We hypothesize that all Tethyan-type ophiolites that formed at spreading ridges were young at the time intraoceanic thrusting began. 


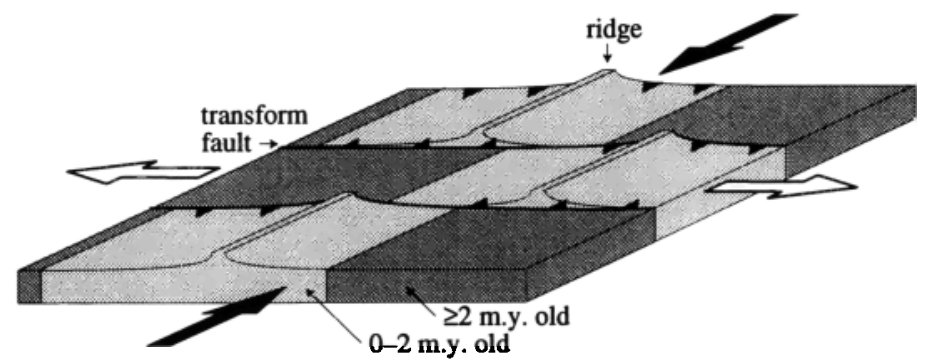

1) c. 95 Ma: initiation of contraction across transform faults

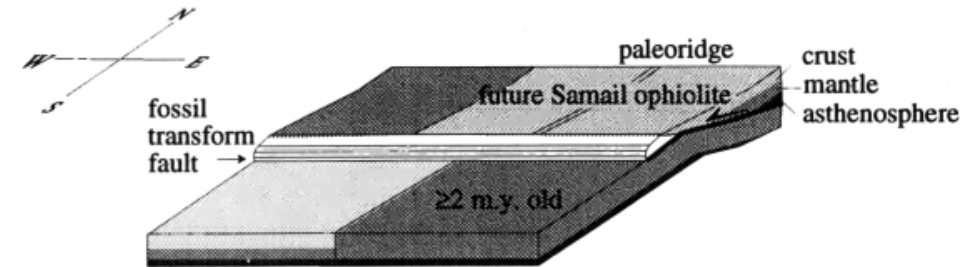

2) $95.7-93.5 \mathrm{Ma}$ : southward thrusting parallel to ridge at $150 \mathrm{~mm} / \mathrm{yr}$

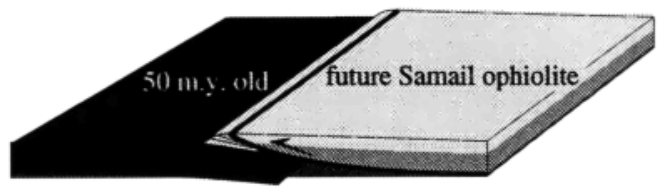

3) 94.9-92.6 Ma: westward thrusting over $50 \mathrm{~m} . y$. old, cold crust at $150 \mathrm{~mm} / \mathrm{yr}$. Emplacement onto the continent occurred by $\sim 78 \mathrm{Ma}$

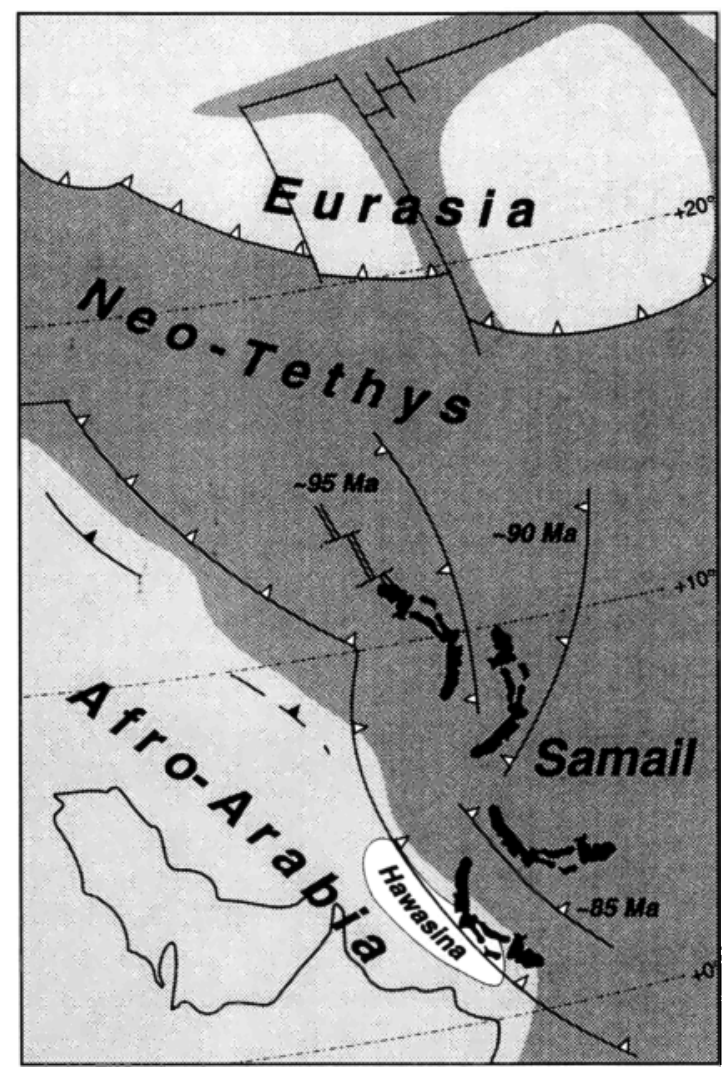
after $400-500 \mathrm{~km}$ of thrusting.

Figure 12. Proposed intraoceanic thrusting history of the (left) Samail ophiolite and (right) simplified paleogeographic reconstructions of the Samail ophiolite [based on Dercourt et al., 1986].

Acknowledgments. Hilal Bin Mohammed Al-Azri, Director of the Geological Survey, Ministry of Petroleum and Minerals, Sultanate of Oman, provided lightning-fast expert logistical support and Arabic coffee. Robert Coleman and Aley El-Shazly kindly helped get the project rolling and provided some samples.
Mike Searle was very generous with maps and directions. Marvin Lanphere and John Pallister provided unpublished Ar/Ar agẹ and samples. Tjerk Peters provided helpful reprints. This paper was reviewed bv Ed Ghent. Randy Koski, and Mike McWilliams and funded by NSF EAR-9204741.

\section{References}

Allemann, F., and T. Peters. The ophioliteradiolarite belt of the North Oman Mountains, Eclogae Geol. Helv., 65, 657697, 1972.

Bechennec, F., J. Le Metour, D. Rabu, C. Bourdillon-de-Grissac, P. de Wever, $M$. Beurrier, and $M$. Villey, The Hawasina Nappes; Stratigraphy, palaeogeography and structural evolution of a fragment of the South-Tethyan passive continental margin, in The Geology and Tectonics of the Oman Region, Geol. Soc. Spec. Publ., vol. 49, edited by A.H. F., M.P. Searle, and A.C. Ries, pp. 213-223, Geol. Soc., London, England, 1990.

Bechennec, F., J. Le Metour, D. Rabu, M. Villey, and M. Beurrier, The Hawasina Basin; A fragment of a starved passive continental margin, thrust over the Arabian Platform during obduction of the Sumail Nappe, Tectonophysics, 151, 323-343, 1988.

Beurrier, M., F. Bechennec, D. Rabu, and G. Hutin, Geological map of As Suwayq, Sheet NF 40-3A, Dir. General of Miner., Oman Minist. of Petrol. and Miner., Muscat, Oman, 1986.
Beurrier, M., C. Bourdillon de Grissac, P. de Wever, and J.L. Lescuyer, Biostratigraphie des radiolarites associées aux volcanites ophiolitiques de la nappe de Samail (Sultanat d'Oman): Consequences tectogenetiques., $C$. R. Acad. Sci. Paris, Sér. 2, 304, 907-910, 1987.

Boudier, F., J.L. Bouchez, A. Nicolas, M. Cannat, G. Ceuleneer, M. Miseri, and R. Montigny, Kinematics of oceanic thrusting in the Oman ophiolites: Model of plate convergence, Earth Planet. Sci. Lett., 75 , 215-222, 1985.

Boudier, F., G. Ceuleneer, and A. Nicolas, Shear zones, thrusts and related magmatism in the Oman ophiolite: Initiation of thrusting on an oceanic ridge, Tectonophysics, 151, 275-296, 1988.

Boudier, F., and R.G. Coleman, Cross section through the peridotite in the Samail ophiolite. southeastern Oman Mountains, J. Geophys. Res., 86, 2573-2592, 1981.

Boudier, F., and A. Nicolas, The Ophiolites of Oman, 401 pp., Elsevier, New York, 1988.

Browning, P., and J.D. Smewing, Processes in magma chambers beneath spreading axes:
Evidence from magmatic associations in the Oman Ophiolite, J. Geol. Soc. London, 138, 279-280, 1981.

Christensen, N.I., and J.D. Smewing, Geology and seismic structure of the northern section of the Oman ophiolite, J. Geophys. Res., 86, 2545-2555, 1981.

Davies, G.F., On the emergence of plate tectonics, Geology, 20, 963-966, 1992.

Dercourt, J., et al., Geological evolution of the Tethys belt from the Atlantic to the Pamirs since the Lias, Tectonophysics, 123, 241-315, 1986.

Dodson, M.H., Closure temperature in cooling geochronological and petrological systems, Contrib. Mineral. Petrol., 40, 259-274, 1973.

Duffield, W.A., and G.B. Dalrymple, The Taylor Creek Rhyolite of New Mexico; a rapidly emplaced field of lava domes and flows, Bull. Volcanol., 52, 475-487, 1990.

Ernewein, M., C. Pflumio, and H. Whitechurch, The death of an accretion zone as evidenced by the magmatic history of the Sumail ophiolite (Oman), Tectonophysics, 151, 247 274, 1988. 
Ghent, E.D., and M.Z. Stout, Metamorphism at the base of the Samail ophiolite, southeastern Oman Mountains, J. Geophys. Res., 86, 2557-2571, 1981.

Giletti, B.J., Geochemical transport and kinetics: Studies in diffusion, 1, Argon in phlogopite mica, Carnegie Inst. Wash., Publ., 634, 107 115, 1974.

Glennie, K.W., M.G.A. Boeuf, M.W. HughesClark, M. Moody-Stuart, W.F.H. Pilar, and B.M. Reinhardt, Geology of the Oman Mountains, Verh. K. Ned. Geol. Mijnbouwkd. Genoot. Ged., 31, 423, 1974.

Gnos, E., The metamorphic rocks associated with the Semail Ophiolite (Sultanate of Oman and United Arab Emirates), Ph.D. thesis, 210 pp., Univ. of Bern, Switzerland, 1992.

Gnos, E., and T. Peters, K-Ar ages of the metamorphic sole of the Semail ophiolite; implications for ophiolite cooling history, Contrib. Mineral. Petrol., 113, 325-332, 1993.

Gradstein, F.M., F.P. Agterberg, J.G. Ogg, J. Hardenbol, P. van Veen, J. Thierry, and $Z$ Huang, A Mesozoic time scale, J. Geophys. Res., 99, 24,051-24,074, 1994.

Gramont, X., J. le Metour, and M. Villey, Geological map of Samad, Sheet NF 40-7C Dir. General of Miner., Oman Minist. of Petrol. and Miner., Muscat, Oman, 1986.

Gregory, R., Melt percolation beneath a spreading ridge; evidence from the Semail peridotite, Oman, in Ophiolites and Oceanic Lithosphere, Geol. Soc. Spec. Publ., vol. 13, edited by I.G. Gass, S.J. Lippard and A.W. Shelton, pp. 55-62, Geol. Soc. London, London, 1984.

Hacker, B.R., Simulation of the metamorphic and deformational history of the metamorphic sole of the Oman ophiolite, $J$. Geophys. Res. 95, 4895-4907, 1990.

Hacker, B.R., The role of deformation in the formation of metamorphic field gradients: Ridge subduction beneath the Oman ophiolite, Tectonics, 10, 455-473, 1991.

Hacker, B.R., Rapid emplacement of young oceanic lithosphere, Science, 265, 1563$1565,1994$.

Hacker, B.R., and J.M. Christie, Brittle/ductile and plastic/cataclastic transitions in experimentally deformed and metamorphosed amphibolite, in The BritteDuctile Transition in Rocks, edited by A.G. Duba, et al., p. 127-148, Geophys. Monogr. Ser., vol. 56, AGU, Washington, D.S., 1990.

Harrison, T.M., Diffusion of ${ }^{40} \mathrm{Ar}$ in hormblende, Contrib. Mineral. Petrol., 78, 324-331, 1981.

Juteau, T., M. Ernewein, I. Reuber, H. Whitechurch, and R. Dahl, Duality of magmatism in the plutonic sequence of the Sumail nappe, Oman, Tectonophysics, 151, 107-136, 1988

Lanphere, M.A., K-Ar ages of metamorphic rocks at the base of the Semail ophiolite Oman, J. Geophys. Res., 86, 2777-2782, 1981 .

Lippard, S.J., Cretaceous high pressure metamorphism in NE Oman and its relationship to subduction and ophiolite nappe emplacement, J. Geol. Soc. London, $140,97-104,1983$.

Lippard, S.J., Petroıvgy ot alkali wehrlite sills in the Oman Mountains, Mineral. Mag., 48, 13 20,1984

Lippard, S.J., and D.C. Rex, K-Ar ages of alkaline igneous rocks in the northern Oman Mountains, NE Arabia, and their relations to rifting, passive margin development and destruction of the Oman Tethys, Geol. Mag., $119,497-503,1982$
Lippard, S.J., A.W. Shelton, and I.G. Gass, The Ophiolites of Northern Oman, 178 pp., 1986.

Lovera, O.M., F.M. Richter, and T.M. Harrison, The 40Ar/39Ar thermochronometry for slowly cooled samples having a distribution of diffusion domain sizes, J. Geophys. Res. 94, 17,917-17,935, 1989.

Manghnani, M.H., and R.G. Coleman, Gravity profiles across the Samail ophiolite, $J$. Geophys. Res., 86, 2509-2525, 1981.

McDougall, I., and T.M. Harrison, Geochronology and Thermochronology by the ${ }^{40} A r^{\beta 9} A r$ Method, 212 pp., Oxford Univ. Press, New York, 1988.

Montigny, R., O. Le Mer, R. Thuizat, and H. Whitechurch, $\mathrm{K}$-Ar and ${ }^{40} \mathrm{Ar} /{ }^{39} \mathrm{Ar}$ study of the metamorphic rocks associated with the Oman ophiolite, Tectonophysics, 151, 345362, 1988.

Moores, E.M., Origin and emplacement of ophiolites, Rev. Geophys., 20, 735-760, 1982.

Nehlig, P., and T. Juteau, Deep crustal seawater penetration and circulation at ocean ridges Evidence from the Oman ophiolite, Mar. Geol., 84, 209-228, 1988a.

Nehlig, P., and T. Juteau, Flow porosities, permeabilities and preliminary data on fluid inclusions and fossil thermal gradients in the crustal sequence of the Sumail ophiolite (Oman), Tectonophysics, 188, 199-222, $1988 \mathrm{~b}$.

Nicolas, A., and F. Boudier, Rooting of the sheeted dike complex in the Oman ophiolite in Ophiolite Genesis and Evolution of the Oceanic Lithosphere, vol. 5, Petrology and Structural Geology, edited by T. Peters, A. Nicolas and R.G. Coleman, pp. 39-53, Kluwer Acad., Norwell, Massachusetts, 1991

Nicolas, A., I. Reuber, and K. Benn, A new magma chamber model based on structural studies in the Oman ophiolite, Tectonophysics, 151, 87-105, 1988.

Pallister, J.S., Obduction dikes: Melting of the continental mantle during emplacement of the Oman ophiolite?, Symposium on Ophiolite Genesis and Evolution of Oceanic Lithosphere, UNESCO-Sultan Qaboos University, Muscat, Oman, 1990.

Pallister, J.S., and C.A. Hopson, Samail ophiolite plutonic suite: Field relations, phase variation, cryptic variation and layering, and a model of a spreading ridge magma chamber, J. Geophys. Res., 86, 2673-2645, 1981

Parsons, B., and J.G. Sclater, An analysis of the variation of ocean floor bathymetry and heat flow with age, J. Geophys. Res., 82, 803-827, 1977.

Pearce, J.A., T. Alabaster, A.W. Shelton, and M.P. Searle, The Oman ophiolite as a Cretaceous arc-basin complex: Evidence and implications, Philo. Trans. R. Soc. London, A300, 299-317, 1981.

Perrin, M., M. Prevot, and F. Bruere, Rotation of the Oman ophiolite and initial location of the ridge in the hotspot reference frame, Tectonophysics, 229, 31-42, 1994.

Peters, T., and B.S. Kamber, Peraluminous, potassium-rich granitoids in the Semai Ophiolite, Contrib. Mineral. Petrol., 118 , 229-238, 1994.

Pflumio, C., Evidences tor polyphased oceanic alteration of the extrusive sequence of the Semail ophiolite from the Salahi block (northern Oman), in Ophiolite Genesis and Evolution of the Oceanic Lithosphere, vol. 5 , Petrology and Structural Geology, edited by T. Peters, A. Nicolas and R.G. Coleman, pp 313-352, Kluwer Acad., Norwell, Massachusetts, 1991.
Rabu, D., Stratigraphy and structure of the Oman Mountains, Doc. B.R.G.M., 221, 262, 1993.

Reuber, I., Complexity of the crustal sequence in the northern Oman ophiolite (Fizh and southern Aswad blocks): The effect of early slicing?, Tectonophysics, 151, 137-165, 1988.

Robbins, G.A., Radiogenic argon diffusion in muscovite under hydrothermal conditions, Master's thesis, Brown Univ., Providence, R.I., 1972.

Robertson, A.H.F., M.P. Searle, and A.C. Ries, The Geology and Tectonics of the Oman Region, in Geol. Soc. London Spec. Publ., vol. 49, pp. 845, Geol. Soc., London, 1990.

Roddick, J.C., The application of isochron diagrams in ${ }^{40} \mathrm{Ar}{ }^{39} \mathrm{Ar}$ dating: A discussion, Earth Planet. Sci. Lett., 41, 233-244, 1978.

Schaaf, F.A., and V. Thomas, Les radiolaires campaniens du Wadi Ragmi l'nappe du Semail, Oman: Un nouveau repere chronologique de l'obduction Omananse, $C$. R. Acad. Sci. Paris, 303, 1593-1598, 1986.

Searle, M.P., Alkaline peridotite, pyroxenite, and gabbroic intrusions in the Oman Mountains, Arabia, Can. J. Earth Sci., 21, 396-406, 1984.

Searle, M.P., S.J. Lippard, J.D. Smewing, and D.C. Rex, Volcanic rocks beneath the Semail ophiolite nappe in the northern Oman Mountains and their significance in the Mesozoic evolution of the Tethys, J. Geol. Soc. London. 137, 589-604, 1980

Searle, M.P., and J. Malpas, Structure and metamorphism of rocks beneath the Semail ophiolite of Oman and their significance in ophiolite obduction, Trans. $R$. Soc. Edinburgh, 71, 247-262, 1980.

Searle, M.P., and J. Malpas, Petrochemistry and origin of sub-ophiolitic metamorphic and related rocks in the Oman Mountains, $J$. Geol. Soc. London, 139, 235-248, 1982.

Tilton, G.R., C.A. Hopson, and J.E. Wright, Uranium-lead isotopic ages of the Samail ophiolite, Oman, with applications to Tethyan ocean ridge tectonics, J. Geophys. Res., 86, 2763-2775, 1981.

Tippit, P.R., E.A. Pessagno, Jr., and J.D. Smewing, The biostratigraphy of sediments in the volcanic unit of the Samail ophiolite, $J$. Geophys. Res., 86, 2756-2762, 1981.

Warburton, J., T.J. Bumhill, R.H. Graham, and K.P. Isaac, The evolution of the Oman Mountains foreland basin, in The Geology and Tectonics of the Oman Region. Geol. Soc. Spec. Publ., vol. 49, edited by A.H. F. M.P. Searle, and A.C. Ries, pp. 419-427, Geol. Soc., London, 1990.

Wendt, I., and C. Carl, The statistical distribution of the mean squared weighted deviation, Chem. Geol., 86, 275-285, 1991.

Wirth, K.R., J.M. Bird, A.E. Blythe, D.J. Harding, and M.T. Heizler, Age and evolution of western Brooks Range ophiolites, Alaska: Results from ${ }^{40} \mathrm{Ar} /{ }^{39} \mathrm{Ar}$ thermochronometry, Tectonics, $12,410-432$, 1993

E. Gnos, and J. L. Mosenfelder, Department of Geological and Environmental Sciences, Stanford University, Stanford, California 943052115. (e-mail: gnos@geo.stanford.edu, jed@ geo.stanford.edu)

B. R. Hacker, Geological Sciences, University of California, Santa Barbara, California 93106-9630. (e-mail: hacker@geol. ucsb.edu)

(Received January 3, 1996;

revised June 7, 1996;

accepted June 23, 1996.) 